\title{
Understanding the hydrochemical evolution of a coastal dune system in SW England using a multiple tracer technique
}

\author{
Debbie Allen ${ }^{1}$, W George Darling ${ }^{1}$, Peter J Williams ${ }^{1}$, Charlie J Stratford ${ }^{2}$, Nick S Robins ${ }^{1}$ \\ ${ }^{1}$ British Geological Survey, Maclean Building, Wallingford, OX10 8BB, UK. \\ ${ }^{2}$ Centre of Ecology and Hydrology, Maclean Building, Wallingford, OX10 8BB, UK. \\ Corresponding author: email dall@bgs.ac.uk, Tel 01491 692391, Fax 01491692345
}

1 Abstract An improved knowledge of the hydrology of coastal dune systems is desirable for successful management of their diverse ecology under a changing climate. As a near-pristine coastal dune spit system, Braunton Burrows (SW England) is an ideal location for the study of the natural processes governing recharge to the dune groundwater system and the evolution of its water quality. Whereas previous investigations have tended to focus on interdune slacks, this study has also given attention to infiltration through the high dunes. Cores were taken through dunes and the resulting sand samples processed to provide information on grain size distribution and porewater chemistry. Groundwater samples were obtained from beneath dunes and slacks. A variety of geochemical techniques were applied including hydrochemistry, stable isotopes and residence time indicators. The unsaturated zone profiles indicate the existence of piston flow recharge with an infiltration rate of $0.75-1 \mathrm{~m} / \mathrm{yr}$, although faster rates probably also occur locally. Groundwater beneath the high dunes gave ages in the range 13-16 yr, compared to the dune slack groundwater ages of 5-7 yr, and an age of $22 \mathrm{yr}$ for groundwater from the underlying mudstone aquifer. The chemistry of waters in both unsaturated and saturated zones is dominated by $\mathrm{Ca}$ and $\mathrm{HCO}_{3}$, supplemented by variable amounts of other ions derived from marine aerosols and limited reaction with sand grains and their coatings. The main chemical evolution of the porewaters occurs rapidly through the mobilisation of surface salt crusts and dissolution of shell carbonate. This situation changes little in the underlying groundwater, though an evolution towards reducing conditions increases the concentrations of redox-sensitive species such as Fe and $\mathrm{Mn}$. The rapid chemical evolution of the infiltrating water means that its composition will respond quickly to changes in the supply of shell material and/or marine salts, which are possible consequences of climate change. However, the residence time measurements suggest the dune aquifer has a relatively long turnover time which will to some extent buffer such changes. The results of the present study should be transferable to natural dune systems in similar coastal situations.

Key words: dune, dune slack, wetland, hydrochemistry, stable isotopes, $\mathrm{SF}_{6}$, unsaturated zone, groundwater. 


\section{$1 \quad$ INTRODUCTION}

Within Europe, coastal dune systems are widely distributed along the Atlantic, Mediterranean, North Sea and Baltic littorals (Doody 2008). They include areas of open mobile sand and more mature vegetated and relatively static dunes. The elevation of the water table within the dunes partially dictates the morphology of the dune fields and determines the elevation at which wetland dune slacks, the flat-floored depressions that occur within the sand dunes, are formed (Stuyfzand 1993; Stratford et al. 2013). The slacks have a shallow water table in summer and may be flooded for much of the winter. The hydrological regime, coupled with the chemistry of the water, dictates the ecological status of the slacks which tend towards a rich and diverse assemblage including rare species (Grootjans et al. 1998; Curreli et al. 2013).

A conceptual understanding of the processes controlling the hydrological regime in dune systems is fundamental to conservation management. As the water table and water chemistry determine the abundance of many slack species and control the vegetation assemblages (Willis et al. 1959) knowledge of the hydrochemical processes and their stability is key to informing management strategies to protect the slack ecosystems. Key questions are:

1. Does infiltration reach the water table exclusively by piston flow?

Conservation management also has to cope with coastal erosion and accretion which impact

2. How does water quality evolve in the unsaturated and saturated zones beneath the high dunes?

3. What kind of timescales are involved in the water movement and evolution?

4. Is water quality stable with time or could it change?

groundwater base levels, changes in rainfall and other natural and sometimes catastrophic events (Robins et al. 2013).

While there have been a number of studies of dune hydrology based on physical parameters such as water levels (e.g. Van der Hagen et al 2008, Vandenbohede et al 2008, Clarke et al. 2010, Davy et al. 2010), there are fewer examples of dune water quality being applied to a

61 better understanding of hydrology and ecology (Stuyfzand 1993; Grootjans et al. 1996; Sival 62 et al. 1999). These studies either tended to focus on dune slacks or, particularly in the case of 
pioneering work on dune system geochemistry (Stuyfzand 1993, Stuyfzand 1989), on systems impacted by processes such as artificial recharge, salinization, decalcification and anthropogenic drainage works. In contrast, this paper describes a study of the hydrogeochemistry of a more natural dune groundwater system at Braunton Burrows in North Devon, England, based on data gathered from unsaturated zone profiles and piezometers beneath both dune ridges and slacks. The techniques used include hydrochemistry, stable isotopes and trace gas age indicators.

Investigations at Braunton Burrows, as at many other coastal dune wetlands, have concentrated mainly on understanding the ecohydrology of the dune slacks with less attention being given to the high dunes. This reflects the importance of the slack ecosystems and their conservation management compared to the sparsely-vegetated high dunes (Davy et al. 2006; 2010). However, understanding the hydrology of dune systems requires knowledge of processes operating across the whole site rather than just the more ecologically complex zones. The present study, therefore, focuses on both the hydrogeochemical processes beneath the dune slacks and the high dunes. The objective is to provide supporting evidence for the understanding of dune spit hydrology in order to better inform the needs for conservation management.

1

\section{BACKGROUND}

Braunton Burrows is a dune spit wetland on the North Devon coast in south-west England (Fig. 1), rising in elevation to $38 \mathrm{~m}$ above Ordnance Datum (aOD) with an area some $10 \mathrm{~km}^{2}$ (Stratford et al. 2013). The spit comprises a series of N-S oriented dunes and slacks which evolved in response to the dynamics of the prevailing wind and sea (Saye and Pye 2007). A narrow zone of low fore-dunes, up to $5 \mathrm{~m}$ high, adjacent to the beach is succeeded inland by sand hills up to $15 \mathrm{~m}$ high separated by a discontinuous belt of slacks. The highest dunes occur just inland from these slacks beyond which is a broad, but poorly defined, belt of lower-lying ground with scattered hillocks and many ephemeral and some permanent pools. Further inland are lesser dunes followed by flat sands with a few scattered small dunes which merge towards cultivated fields. The slacks mainly remain dry in winter with ephemeral wet weather pools (Davy et al. 2006; 2010). 
97 The dunes rest on an estuarine clay layer forming the base of the small rain-fed aquifer in the sand (Burden 1998). The underlying Pilton Mudstone Formation (Devonian) forms a lowyielding aquifer, with little to no hydraulic contact between this and the sand aquifer. Groundwater level data from the piezometer network has been used to identify a groundwater divide within the sands parallel to the beach some two-thirds of the way inland towards the rear of the dune-field (Fig. 2). Groundwater discharges both to the beach beneath the foredune and inland to estuarine deposits which form low-lying meadows. The water table reaches a maximum elevation of $8 \mathrm{~m}$ aOD in winter along the axis of the groundwater divide (Stratford et al. 2013). There has been a decline in rainfall over the last 40 years which has caused a reduction in water table elevation which in turn has degraded the slack ecosystems (Robins and Jones 2013). Comparison with other west coast dune sites in England and Wales indicates that Braunton Burrows has been most impacted by change due to the decline in effective rainfall, making a better understanding of its hydrology a priority.

\section{SAMPLING AND ANALYSIS}

3

Three new uncored shallow dipwells (BB1, BB2 and BB3, see Table 1, Fig. 1) were handaugered into the dune slacks to supplement an existing groundwater level monitoring network and to provide access for groundwater sampling. Subsequently a trial 'deep' cored dipwell (D1) was hammer drilled to a depth $\sim 6 \mathrm{~m}$ on a high dune at the eastern end of the main slack transect in October 2011. Core was delivered in $1 \mathrm{~m}$ lengths within a polythene sleeve; recovery varied between 90 and 95\%. The core was sub-sampled at $0.1 \mathrm{~m}$ intervals by slicing through the sleeve with aliquots stored in airtight glass vials later being used to test an offline preparation method for deuterium $\left(\delta^{2} \mathrm{H}\right)$ analysis (see 4.3 below). The hole remained open during drilling with only the upper $\sim 0.3 \mathrm{~m}$ being dry and friable. The remainder of the sand was moist and comprised consistently fine-grained to silt-grade material. The hole did not reach the water table but was lined with $36 \mathrm{~mm}$ diameter plastic pipe and capped top and bottom to allow future access if required.

Four additional deep cored dipwells were hammer-drilled using a Cobra TT percussion drill along the line of the main slack dipwell transect (Fig. 1) to depths up to 9m (Table 1) during November 2011. Continuous sampling of the unsaturated zone was achieved in the first three dipwells (D2, D3 and D4) with partial sampling in D5 nearest the shore. Small sub-samples 
131 taken at $0.1 \mathrm{~m}$ intervals from the D2 and D4 cores were transferred into airtight glass vials for $132 \delta^{2} \mathrm{H}$ analysis of the sand moisture. All cored sections from D2, D3, and D4 were then sliced into $0.2 \mathrm{~m}$ intervals from which about $40 \mathrm{~mm}$ was deposited into pre-weighed sealable containers to measure gravimetric moisture content and the remainder transferred to sealed plastic bags and refrigerated for subsequent centrifugation in the laboratory. Dipwells D3, D4 and D5 penetrated the water table, below which coring ceased to be effective. Piezometers were completed and cased to below water level, where possible, with $1 \mathrm{~m}$ of permeable casing at the bottom of the hole.

140 Owing to a problem of sand fall-in during drilling which affected the top sample of many of the core runs, several samples from each piezometer had to be discarded, leaving a number of small gaps in each of the resulting profiles (Section 4.3).

The sites were chosen to minimize the influence of disturbance by trees and their roots. Details of vegetation at each site have been recorded (Table 1) from a vegetation survey that took place in 2012 .

Sand moisture contents were calculated from the weight loss observed after heating subsamples to $75^{\circ} \mathrm{C}$ for 48 hours. The dried samples from D3 and D4 were subsequently used for grain size analysis.

The bagged sands were refrigerated and centrifuged soon after returning from the field. Subsamples were transferred to centrifuge buckets made from inert material and centrifuged at $14,000 \mathrm{rpm}$ for 25 minutes. The drained waters were passed through $0.45 \mu \mathrm{m}$ filters and split between two HDPE bottles per sample. One of each pair of bottles was acidified to $1 \%$ with Aristar nitric acid for determination of cations. In addition, aliquots were taken for standard $\delta^{2} \mathrm{H}$ and $\delta^{18} \mathrm{O}$ analysis from those samples which yielded sufficient volume. Specific electrical conductivity (SEC) was determined on the unacidified sample splits.

160 Owing to ingress of fine silty sand during an initial attempt to sample groundwater standing in D3, D4, and D5 the piezometers were re-drilled to a depth of $9.2 \mathrm{~m}$ (Table 1) and completed with a $1 \mathrm{~m}, 36 \mathrm{~mm}$ diameter screen wrapped in a geotextile filter membrane section at the bottom of the piezometer. This enabled low turbidity samples to be obtained from $D_{\text {new }} 4$ and $D_{\text {new }} 5$, but the water column in $D_{\text {new }} 3$ was too small to sample. 
165 All piezometer groundwater samples, beneath both dune slack and high dune, were pumped using a portable peristaltic pump and where feasible $\mathrm{pH}$, Eh, and dissolved oxygen were determined by electrodes in a flow-through cell. SEC and temperature (determined by thermistor thermometer) were also measured. Sampling commenced when purging was completed as indicated by stable field measurements, which sometimes involved emptying the piezometer and allowing it to refill before sampling. Alkalinity as $\mathrm{HCO}_{3}$ was measured on site with a digital titrator. The bedrock borehole was artesian during sampling and was sampled using the same methods as the piezometers.

174 The groundwaters from $\mathrm{D}_{\text {new }} 4$ and $\mathrm{D}_{\text {new }} 5$ along with shallow slack dipwells 1,2 and 3, PR2 and the underlying Pilton Mudstone formation were sampled for major and minor ion chemistry, stable isotopes and sulphur hexafluoride $\left(\mathrm{SF}_{6}\right)$.

Samples of groundwater were collected in pairs of HDPE bottles, one of which was acidified to $1 \%$ with nitric acid, before refrigeration and transfer to the laboratory. Unfiltered groundwater samples were collected for $\delta^{18} \mathrm{O}, \delta^{2} \mathrm{H}$ and $\delta^{13} \mathrm{C}$ analysis. Samples for $\mathrm{SF}_{6}$ (sulphur hexafluoride) measurement were collected by the displacement method into glass bottles contained within metal cans to minimise atmospheric contamination (Oster 1994).

Grain size analysis was carried out on a Mastersizer 2000, which uses laser diffraction to measure particle sizes. Selected grain samples were analysed by SEM. Determination of major and minor ions was carried out using ICP-MS for cations and ion chromatography for anions. Ionic balances were found to be within $\pm 10 \%$, a relatively wide error band but most likely due to the dilutions necessary for the analysis of these low-volume samples. Stable isotopes were measured by isotope ratio mass spectrometry following offline preparation by $\mathrm{CO}_{2}$ equilibration $\left(\delta^{18} \mathrm{O}\right)$, zinc reduction $\left(\delta^{2} \mathrm{H}\right)$ and acidification with $\mathrm{H}_{3} \mathrm{PO}_{4}\left(\delta^{13} \mathrm{C}-\mathrm{TIC}\right)$, with precisions of $\pm 0.1 \%, \pm 1 \%$ and $\pm 0.2 \%$ respectively. $\mathrm{SF}_{6}$ analysis was performed by GC-ECD following cryogenic pre-concentration, with a detection limit of $0.1 \mathrm{pmol} / \mathrm{L}$. 


\section{4. $\quad$ RESULTS}

\subsection{Grain size and mineralogy}

The grain size analysis profiles for D3 and D4 are consistent with a well-sorted average $\mathrm{D}_{10}$ and $\mathrm{D}_{90}$ of $120 \mu \mathrm{m}$ and $280 \mu \mathrm{m}$ respectively, i.e. 'very fine to medium sand'. No anomalous silt or clay layers were penetrated. The full range of grain sizes within the profiles $\mathrm{D}_{10}$ and $\mathrm{D}_{90}$ are from $97-320 \mu \mathrm{m}$ (Fig. 3).

SEM analysis of selected grain samples (2.2 to $2.4 \mathrm{~m}$ in D2, 2.4 to $2.6 \mathrm{~m}$ in D3 and D4) are consistently dominated by calcite derived from shell debris. The samples comprise $\mathrm{Ca}$ and Mg-rich shell fragments and fossils, quartz grains coated with illite, smectite, chlorite and thin iron coatings, with potassium and plagioclase feldspars and some faecal pellets.

\subsection{Unsaturated zone moisture content}

215 The gravimetric porewater profile in the unsaturated zones in the high dune (Fig. 4) shows

216 that dipwell D2 has a moisture content in the range $3-9 \%$ while D3 has $5-12 \%$. The 217 unsaturated zone porewater profile for D4 is $5-11 \%$ to within $\sim 0.5 \mathrm{~m}$ above the standing 218 water level, below which moisture content rises to between $21-24 \%$ through the capillary 219 fringe.

\subsection{Unsaturated zone hydrochemistry and isotopes}

The major ion chemistry of the dune porewaters (Table 2) is variable, with total dissolved solids (TDS) within the range $245-635 \mathrm{mg} / \mathrm{l}$. The chemistry of the porewaters is dominated by $\mathrm{Ca}$ and $\mathrm{HCO}_{3}$ from the dissolution of shell debris, and is supplemented by variable proportions of $\mathrm{Na}$ and $\mathrm{Mg}$ (cations) and $\mathrm{Cl}$ and $\mathrm{SO}_{4}$ (anions) from marine aerosol sources.

228 Most stable isotope results for the unsaturated sands are restricted to $\delta^{2} \mathrm{H}$ because the small amount of sample usually available was only sufficient for the direct reduction technique

230 (based on that of Turner and Gailitis, 1988). These results are shown in Fig. 5. However, in 231 some cases both $\delta^{2} \mathrm{H}$ and $\delta^{18} \mathrm{O}$ could be measured on centrifuged water using standard 
preparation methods. Values of $\delta^{2} \mathrm{H}$ obtained in this way are included in Fig. 5, showing that the results are generally comparable within measurement error to the direct reduction data.

\subsection{Saturated zone hydrochemistry, stable isotopes and sulphur hexafluoride}

The analytical results for the groundwater samples collected from below the dune slacks and high dunes are supplemented by a sample from the bedrock (Pilton Mudstone Formation) which is hydraulically isolated from the dune aquifer by estuarine clay. The major ion chemistry for all groundwater samples shows anions are dominated by $\mathrm{HCO}_{3}$ (Table 3). The cations are dominated by $\mathrm{Ca}$ below the slacks 1, 2 and PR2, with increasing $\mathrm{Na}$ dominance below high dune samples $\mathrm{D}_{\text {new }} 4$ and $\mathrm{D}_{\text {new }} 5$, dune slack 3 and the bedrock borehole.

$\mathrm{O}, \mathrm{H}$ and $\mathrm{C}$ stable isotopes were measured on samples from the saturated zone in the high dune $\mathrm{D}_{\text {new }} 4$ and $\mathrm{D}_{\text {new }} 5$ dipwells, dune slack PR2 and bedrock (Table 3).

$\mathrm{SF}_{6}$ values (Table 4) are corrected for excess air (Darling et al. 2012) on the assumption that this is present at $1.5 \mathrm{ccSTP} / 1$, based on sand-column experiments of Holocher et al. (2002). An excess air correction of $2.5 \mathrm{ccSTP} / 1$ is used for the sample from the Pilton Mudstone Formation because of some uncertainty about the recharge mechanism. The $\mathrm{SF}_{6}$ residence times assume a mean annual air temperature of $10^{\circ} \mathrm{C}$.

DISCUSSION

\subsection{The recharge process}

\subsubsection{Unsaturated zone}

Unsaturated zone $\mathrm{Cl}$ (Fig. 6) and $\delta^{2} \mathrm{H}$ profiles (Fig. 5) appear to reflect the rate of infiltration into the high dunes. A high $\mathrm{Cl}$ pulse normally occurs at the beginning of each autumn rainfall period flushing dry deposition consisting mainly of $\mathrm{Cl}, \mathrm{Na}$ and $\mathrm{SO}_{4}$ from the summer period into the newly infiltrating rain-fed recharge (Malcolm \& Soulsby 2001). While $\mathrm{Na}$ and $\mathrm{SO}_{4}$ are affected by sorption and other exchange processes $\mathrm{Cl}$ is more conservative and tends to remain in the profile as a peak. However, the conventional pattern of dry summers and wet 
winters is not consistent with recent notably wet summers in 2007 and 2008, and a particularly wet July in 2009, all of which are likely to have perturbed the normal sequence to some extent.

While there may be some ambiguity in the interpretation of the observed $\mathrm{Cl}$ peaks as infiltration rate indicators, stable isotopes can also be used in this role. Colder winter rainfall tends to have a more negative $\delta^{2} \mathrm{H}$ composition than generally warmer summer rainfall. The record from the nearest rainfall isotope monitoring station at Wallingford demonstrates this (Fig. 5), with particularly negative compositions during the winters of 2008/09 and 2009/10. Although Wallingford is approximately $150 \mathrm{~km}$ to the east (Fig. 1) and its rainfall has undergone some relative depletion by the 'continental effect' (Darling and Talbot 2003), it is likely to be broadly similar to the magnitude of the cyclicity at Braunton Burrows. Significant variations in the $\delta^{2} \mathrm{H}$ profiles due simply to near-surface evaporative fractionation appear to be ruled out by the centrifuged porewater samples, whose $\delta^{2} \mathrm{H}$ and $\delta^{18} \mathrm{O}$ values plot on a slope of $\sim 6$ (Fig. 7) rather than the 2-3 typical of soil moisture evaporation (Barnes and Allison, 1988).

Based on their apparent cyclicity, both the $\delta^{2} \mathrm{H}$ and $\mathrm{Cl}$ profiles from D2 and D4 suggest a moisture infiltration rate of 0.75 to $1 \mathrm{~m} / \mathrm{yr}$ (Figs 5 and 6). Diffusion tends to blur the annual cycles at greater depth. The cyclicity in the upper parts of the profiles clearly confirms that a key transport mechanism in the unsaturated zone is piston flow (as new water arrives at the top of the column, old water is displaced at the bottom and the whole column moves uniformly downwards). The infiltration rate indicated by the $\mathrm{Cl}$ and $\delta^{2} \mathrm{H}$ profiles in dipwells D2 and D4 suggests that it would take 6-7.5 yr and 5-6 yr for infiltration to reach the water table at D4 and D5 respectively.

292 However, the moisture infiltration rate of 0.75 to $1 \mathrm{~m} / \mathrm{yr}$ suggested by the $\delta^{2} \mathrm{H}$ and $\mathrm{Cl}$ profiles 293 from D2 and D4 should also be considered in the context of the moisture content data (Fig. 4) and local meteorological data. The median moisture contents of D2 and D4 are $\sim 6 \%$ and $8 \%$ by weight respectively, implying volumetric water contents of $\sim 10 \%$ and $13 \%$ based on a dry bulk density for dune sand of $\sim 1600 \mathrm{~kg} / \mathrm{m}^{3}$ (Ritsema and Dekker, 1994). These volume percentages translate to water contents of $100-130 \mathrm{~mm}$ for an infiltration rate of $1 \mathrm{~m} / \mathrm{yr}$. Rainfall at Chivenor ( $5 \mathrm{~km} \mathrm{E}$ of the dunes) over the five years preceding the month of sampling averaged 925 $\mathrm{mm} / \mathrm{yr}$ (based on data from 
http://www.metoffice.gov.uk/climate/uk/stationdata/chivenordata.txt). Actual evapotranspiration data from the local MORECS (Meteorological Office Rainfall and Evapotranspiration Calculation System) Square 165 for the same period gives an average effective rainfall of $45 \%$, implying an effective rainfall of $\sim 400 \mathrm{~mm} / \mathrm{yr}$ on the dunes, nearly all of which should theoretically infiltrate owing to the very limited potential for runoff. The calculated profile water contents would then amount to some $25-33 \%$ of the effective rainfall/recharge. While there is some uncertainty over the true value of actual evapotranspiration for the dunes, it is unlikely to be significantly different from the MORECS average. The disparity may be explained by preferential flow, which can include macropore flow but also (and probably more significant for sand) 'unstable wetting': for example a homogeneous dune sand lysimeter experiment by Hendrickx and Dekker (1994) found that at a depth of $\sim 0.5 \mathrm{~m}$, the sand volume was only patchily wetted after 4 months of rainfall totalling $400 \mathrm{~mm}$. The existence of such 'fingering' in natural dune sands seems likely but it would take many more than the three profiles reported here to characterise satisfactorily.

The existence of preferential flow implied by the meteorological data would mean that much of the infiltration to the water table was moving rather faster than the maximum rate of $1 \mathrm{~m} / \mathrm{yr}$ implied by the profile fluctuations in Figs 5 and 6 . This could still be occurring via piston flow; the rather wetter profile D4 indicates a somewhat faster infiltration rate than the drier D2 (Figure 5), so it may be that the rate rises proportionally with moisture content in wetter fingers of sand.

\subsubsection{Groundwater}

Groundwater recharged during the past four decades can in principle be dated on the basis of its $\mathrm{SF}_{6}$ concentration given certain assumptions about likely recharge conditions, principally mean annual air temperature but also the amount of excess air (EA) incorporated during recharge ( 4.4 above). The residence times in Table 4 have been calculated on a 'piston flow' model of groundwater flow (Darling et al., 2012), though in reality most pumped groundwater is a mixture of waters from all the flow lines reaching the discharge point, so the ages given in Table 4 should be regarded as mean residence times (MRTs).

32 The results show that groundwater below the sampled high dunes had MRTs of $\sim 13$ and $\sim 16 \mathrm{yr}$, and below the dune slacks of $\sim 6 \mathrm{yr}$. The greater thickness of the unsaturated zone 
beneath the high dunes seems one obvious reason. There is, however, some uncertainty about the lag on the $\mathrm{SF}_{6}$ 'clock' during transit through the unsaturated zone (Darling et al. 2012),

336 therefore, some mixing with older stored waters could also be contributing. Simple binary 337 groundwater age mixing can often be detected by plotting $\mathrm{SF}_{6}$ versus CFC 338 (chlorofluorocarbon) concentrations. However, owing to the reducing conditions in most of 339 the groundwaters, CFC analyses were not undertaken because of probable degradation effects 340 (Sebol et al. 2007).

342 The MRTs in the dune system can be compared to that of the Pilton Mudstone aquifer as sampled at the Saunton Sands Golf Club (Bedrock BH, Fig. 1), which gives an MRT of

$344 \sim 22$ yr. As a locally confined aquifer this would be expected to contain older water than the overlying dune system. While the calculated age is not much greater than those of the dunes water, little is known of the turnover of the Pilton Mudstone aquifer or its excess air content (see 4.4 above), which if higher than estimated would result in an older age.

\subsection{Evolution of water quality}

\subsubsection{Unsaturated zone}

The chemistry of the unsaturated zone porewaters (Table 2) derives from a variety of inputs. Much of the $\mathrm{Na}, \mathrm{Cl}$ and $\mathrm{SO}_{4}$ must be derived from deposition of marine aerosols, but superimposed on this are contributions from the mineralogy of the sand including calcareous shell debris and fossiliferous calcite, quartz coated with illite, smectite, chlorite and Fe compounds as well as potassic and plagioclase feldspars. Variable dissolution of these minerals accounts for most of the fluctuations in the minor element hydrochemistry of the dune porewaters. The lack of any rise in $\mathrm{SO}_{4}$ with depth confirms the rather limited mineralogical evidence (see 4.1 above) for the absence of pyrite in the dune sands, which would tend to oxidise to sulphate.

The carbonate system is more consistent. The $\mathrm{Mg} / \mathrm{Ca}$ molar ratios found in the porewaters of piezometers D2, D3 and D4 increase with depth (Fig. 8) reflecting increasing Mg dissolution.

365 The near-constant $\mathrm{Sr} / \mathrm{Ca}$ ratios (Fig. 9) suggest that incongruent dissolution of calcite is not 366 the cause and that the increased $\mathrm{Mg}$ is coming from another source, probably the Mg-rich 367 shell debris. 
370 The groundwaters in the shallow sand aquifer continue to show the influence of mineralogy and marine aerosols. The carbonate system again dominates the chemistry seen in the groundwaters, most markedly at the slacks BB1, BB2 and PR2. These groundwaters are more carbonate-dominated than the porewaters. Increasing influence of marine aerosols as $\mathrm{Na}$ and $\mathrm{Cl}$ is seen below the high dunes and slack BB3 putting them closer within the main group of porewaters (table 2). Dune slack BB3 is seen to behave slightly differently to the others slacks; its higher marine aerosol signal may be due to its proximity to the sea.

The $\mathrm{Mg} / \mathrm{Ca}$ molar ratios for the D4 and D5 groundwaters (Fig. 8) highlight their consistency with the porewaters as they plot as a continuation of the porewater series. $\mathrm{Mg}$ is seen to increase with depth as with the porewaters. The $\mathrm{Sr} / \mathrm{Ca}$ ratios of the groundwaters (Fig. 9) are, however, lower than those of the porewaters with an increase in Sr possibly consistent with the occurrence of incongruent dissolution of calcite.

The high Fe and Mn present in the groundwaters beneath the slacks (PR2, BB1 and BB2) and high dunes are a consequence of the reducing conditions illustrated by the dissolved oxygen and Eh values. Both $\mathrm{Fe}$ and $\mathrm{Mn}$ are found as dissolved ions due to the reduction of iron oxide and manganese oxide mineral coatings and minerals found within the sand grains. This is in contrast to the low Fe and Mn concentrations found in the porewaters. The exception to this is the dune slack groundwater BB3 with Fe and Mn concentrations comparable to the dune porewaters. Although the dissolved oxygen is again low in this sample, the redox is elevated, this together with the low Fe and Mn points to a more oxygenated sample as with the porewaters. It is likely that a greater amount of recharge occurs through the flooded slacks than beneath the dunes (D Clarke, personal communication), and this may be a more recent recharge signal (BB3 gives the youngest MRT). The proximity of BB3 to the sea may account for the raised SEC and increased marine aerosol signal.

397 Groundwater samples from the dipwells D4 and D5 and dune slack piezometer PR2 gave $\delta^{13} \mathrm{C}_{\text {TIC }}$ values of $-9.5,-9.3$ and $-8.9 \%$ respectively. The similarity of the values suggests rather consistent carbonate system conditions in the dune groundwaters. The total inorganic carbon (TIC) in the groundwaters beneath the dunes is likely to arise from reaction between shelly fragments in the sand and the $\mathrm{CO}_{2}$ generated by soil bacterial respiration. Reaction 
402 between soil $\mathrm{CO}_{2} \quad(\sim-26 \%)$ and marine-derived calcite $(\sim 0 \%)$ initially results in a $\delta^{13} \mathrm{C}_{\mathrm{TIC}}$ value of $\sim-13 \%$. Subsequent dissolution-reprecipitation processes will tend to drive the value towards the calcite composition, making it less negative as observed in the dune sand groundwaters. However, this can only occur under closed-system conditions, i.e. no further supply of soil $\mathrm{CO}_{2}$. This is consistent with the commencement of the $\mathrm{SF}_{6}$ "clock" well above the water table lying at the base of the unsaturated zone (5.1.2 above). The evolution of the $\delta^{13} \mathrm{C}_{\mathrm{TIC}}$ from initial equilibrium of $\sim-13 \%$ requires a certain amount of time, so the MRTs indicated by $\mathrm{SF}_{6}$ (13 and $16 \mathrm{yr}$ respectively) are consistent with this interpretation. Methanogenesis, an alternative explanation for the shift in $\delta^{13} \mathrm{C}_{\mathrm{TIC}}$ via co-produced isotopically heavy $\mathrm{CO}_{2}$ (Stuyfzand 1993) can be ruled out on the basis of detectable $\mathrm{NO}_{3}$ and absence of evidence for $\mathrm{SO}_{4}$ reduction (Table 3), backed up by measurements of dissolved $\mathrm{CH}_{4}$ in two slack groundwaters (PR2 and Orchid) which were both extremely low at $<1 \mu \mathrm{g} / \mathrm{L}$.

By comparison, the Pilton Mudstone formation gave $\delta^{13} \mathrm{C}_{\mathrm{TIC}}$ values of $-13.6 \%$ which would be consistent with relatively young groundwaters in a locally confined aquifer.

Nitrate concentrations in the unsaturated zone and the groundwaters are generally low, the only exception to this being the top (0-200 mm) section of D2 and D3 which have 33 and $120 \mathrm{mgl}^{-1} \mathrm{NO}_{3}$ respectively. (The top $50 \mathrm{~mm}$ of D4 was unavailable for sampling which may explain the lack of a high $\mathrm{NO}_{3}$ concentration being found in this profile.) The elevated $\mathrm{NO}_{3}$ at the top of the soil zone may be a consequence of atmospheric deposition along with plant and animal inputs as all material was used to provide porewater. Nitrate concentrations within the underlying bedrock aquifer (Pilton Mudstone Formation) are also low.

This study of a coastal dune system in SW England has used a range of environmental tracers to address the four key questions posed in the Introduction.

First, while this study has found evidence for the existence of piston flow through the unsaturated zone, the imbalance between indicated and likely recharge rates points to the existence of some preferential flow, probably mainly due to unstable wetting rather than macropore flow, which would seem less likely to be significant in a dunes context. It may be 
the case that even in locally wetter zones, piston flow still predominates, but at a faster rate.

437 To get a better indication of this, a higher density of unsaturated zone profiling would be

438 required.

440 Second, water quality in the unsaturated zone of the dunes aquifer is predominantly the result

441 of the deposition of marine aerosols and the dissolution of shell fragments. There appears to

442 be relatively little reaction with the sand matrix. Saturated zone water quality largely matches

443 porewater compositions at the base of the unsaturated zone, implying that if faster infiltration

444 routes exist, the chemistry of these waters has already evolved a similar chemistry.

446 Third, it appears that the main hydrochemical evolution of unsaturated zone porewater occurs

447 very rapidly, in months rather than years. This is because comparatively rapid processes like

448 the mobilization of surface salt crusts and the dissolution of shell calcite tend to dominate the

449 water quality. However, minor changes like the slow build-up of $\mathrm{Mg}$ take longer because of

450 the reaction kinetics. The main change in the underlying groundwater is that the low- $\mathrm{O}_{2}$

451 conditions appear to be slowly reducing the concentrations of ions like $\mathrm{SO}_{4}$ and $\mathrm{NO}_{3}$ and increasing the concentrations of $\mathrm{Fe}$ and $\mathrm{Mn}$, while also favouring the mineralisation of carbon. Incongruent mobilisation of $\mathrm{Mg}$ continues. Measured mean residence times of up to $16 \mathrm{yr}$ indicate that dissolved $\mathrm{O}_{2}$ is relatively persistent with time, suggesting that the bacterial mediation of reducing reactions is not highly developed.

Fourth, while this study did not include a water quality monitoring element, certain conclusions can be drawn about the effects of secular changes in conditions, whether climatic or morphological. Gradual changes in mean rainfall and temperature are unlikely to affect water quality significantly, but changes in the supply of marine salts (e.g. via much stormier conditions) or the supply of shell fragments (e.g. because of dune migration) could have a rather greater impact on water quality.

The results of this study are applicable to other unmodified dune spit systems and hence their future environmental management. 


\section{Acknowledgments}

471 The authors acknowledge the assistance of Ned Hewitt (CEH), Ian Woods (BGS) and 472 Martin Hollingham (independent) for help in installing piezometers. Derek Clarke 473 (Southampton University) is thanked for sharing his knowledge of dune systems as is Antoni 474 Milodowski (BGS) for SEM of the sand grains. BGS and CEH labs at both Wallingford and 475 Keyworth are thanked for the analytical results. Sam Amy (CEH) is thanked for vegetation 476 classification data. MORECS data is licensed under Crown Copyright from the UK Met 477 Office (010045532). The reviewers are thanked for their constructive comments and ideas. 478 DA, WGD, NSR, and PJW publish with the permission of the Executive Director, British 479 Geological Survey (NERC).

480 
482 Barnes, C.J., Allison, G.B. 1988. Tracing of water movement in the unsaturated zone using stable isotopes of hydrogen and oxygen. J. Hydrol. 100, 143-76. doi: 10.1016/00221694(88)90184-9

485

Burden, R.J. 1988. A hydrological investigation of three Devon sand dune systems: Braunton Burrows, Northam Burrows and Dawlish Warren. PhD Thesis, University of Plymouth.

Clarke, D., Sanitwong Na Ayutthaya, S. 2010. Predicted effects of climate change, vegetation and tree cover on dune slack habitats at Ainsdale o the Sefton Coast, UK. J Coast Conservat 14, 115-25. doi: 10.1007/s11852-009-0066-7

490 Curreli, A., Wallace, H., Freeman, C., Hollingham, M., Stratford, C., Johnson, H., Jones, L. 2013. Eco-hydrological requirements of dune slack vegetation and the implications of climate change. Science of the Total Environment 443, 910-919. doi: 10.1016/j.scitotenv.2012.11.035

494 Darling, W.G., Talbot, J.C. 2003. The O \& H stable isotopic composition of fresh waters in the British Isles. 1. Rainfall. Hydrology \& Earth System Sciences 7, 163-181.

Darling, W.G., Bath, A.H., Talbot, J.C. 2003. The O \& H stable isotopic composition of fresh waters in the British Isles. 2. Surface waters and groundwater. Hydrology \& Earth System Sciences 7, 183-195.

499 Darling, G. Gooddy, D.C. MacDonald, A.M., Morris, B.L. 2012. The practicalities of using $500 \mathrm{CFCs}$ and $\mathrm{SF}_{6}$ for groundwater dating and tracing. Applied Geochemistry 27. 1688-1697. doi: 10.1016/j.apgeochem.2012.02.005

502 Davy, A.J., Grootjans, A.P., Hiscock, K., Petersen, J. 2006. Development of eco-hydrological guidelines for dune habitats - Phase 1. English Nature Reports, Number 696.

504 Davy, A.J., Hiscock, K.M., Jones, M.L.M., Low, R., Robins, N.S., Stratford, C.J. 2010. 505 Ecohydrological guidelines for wet dune habitats - Phase 2. Environment Agency Report.

506 Doody, J.P. 2008. Sand dune inventory of Europe, $2^{\text {nd }}$ edn. National Coastal Consultants and EUCC - The Coastal union, in association with the IGU Coastal Commission, Peterborough.

508 Grootjans, A.P., Sival, F.P., Stuyfzand, P.J. 1996. Hydro-geochemical analysis of a degraded 509 dune slack. Vegetatio 126, 27-38.

510 Grootjans, A.P., Ernst, W.H.O., Stuyfzand, P.J. 1998. European dune slacks: strong 511 interactions of biology, pedogenisis and hydrology. Tree 3, 96-100.

512 Hendrickx, J.M.H., Dekker, L.W. 1991. Experimental evidence of unstable wetting fronts in 513 non-layered soils. In: Proc. Natl. Symp. on Preferential Flow. Chicago, Ill. 16-17, Dec. 1991, 514 St. Joseph, Mich.: Am. Soc. Agric. Eng., 22-31. 
515 Holocher, H., Peeters, F., Aeschbach-Hertig, W., Hofer, M., Brennwald, M., Kinzelbach, W.,

516 Kipfer, R. 2002. Experimental investigations on the formation of excess air in quasi-saturated

517 porous media. Geochimica et Cosmochemica Acta 66, 4102-4117. doi: 10.1016/S0016-

$518 \quad 7037(02) 00992-4$

519 Malcolm, R., Soulsby, C. 2001. Hydrogeochemistry of groundwater in coastal wetlands:

520 implications for coastal conservation. Science of the Total Environment 265, 269-280. doi:

521 10.1016/S0048-9697(00)00663-X

522 Oster, H. 1994. Datierung von Grundwasser mittels FCKW: Voraussetzungen, Möglichkeiten

523 und Grenzen, Dissertation,Inst. für Umweltphys., Universität Heidelberg.

524 Ritsema, C.J., Dekker, L.W. 1994. Soil moisture and dry bulk density patterns in bare dune 525 sands. Journal of Hydrology 154, 107-131.

526 Robins, N.S., Jones, M.L.M. 2013. Ecohydrological 'Indicators of alteration' - a robust 527 measure of change in dune slacks . Ecohydrology 6, 256-263. doi: 10.1002/eco.1264

528 Robins, N.S., Pye, K., Wallace, H. 2013. Dynamic coastal dune spit: the impact of

529 morphological change on dune slacks at Whiteford Burrows, South Wales, UK. Journal of

530 Coastal Conservation 17, 473-482. doi: 10.1007/s11852-013-0245-4

531 Saye, S.E., Pye, K. 2007. Implications of sea level rise for coastal dune habitat conservation 532 in Wales, UK. Journal of Coastal Conservation 11, 31-52. doi: 10.1007/s11852-007-004-5

533 Sebol, L.A., Robertson, W.D., Busenberg, E., Plummer, L.N., Ryan, M.C., Schiff, S.L. 2007. 534 Evidence of CFC degradation in groundwater under pyrite-oxidizing conditions. J. Hydrol. 535 347, 1-12. doi: 10.1016/j.jhydrol.2007.08.009

536 Sival, F.P., Strijkstra-Kalk, M. 1999. Atmospheric deposition of acidifying and 537 eutrophicating substances in dune slacks. Water Air Soil Pollut. 116, 461-77.

538 Stratford, C., Robins, N.S., Clarke, D., Jones, M.L.M. Weaver, G. 2013. An ecohydrological 539 review of dune slacks on the west coast of England and Wales. Ecohydrology 6, 162-171. 540 doi: $10.1002 /$ eco.1355.

541 Stuyfzand, P. J. 1989. A new hydrochemical classification of watertypes. IAHS Publ 182, 542 89-98.

543 Stuyfzand, P.J. 1993. Hydrochemistry and hydrology of the coastal dune area of the western

544 Netherlands. PhD thesis, Vrije Universiteit Amsterdam.

545 Turner, J.V., Gailitis, V. 1988. Single-step method for hydrogen isotope ratio measurement of 546 water in porous media. Analytical Chemistry 60, 1244-1246. doi: 10.1021/ac00162a030 
547 Vandenbohede, A. Luyten, K. Lebbe, L.2008. Effects of Global Change on Heterogeneous

548 Coastal Aquifers: A Case Study in Belgium. Journal of Coastal Research 24, 160 - 170.

549 doi:10.2012/05-0447.1

550 Van der Hagen, H.G.J.M., Geelen, L.H.W.T., de Vries, C.N. 2008. Dune slack restoration in

551 Dutch mainland coastal dunes. Journal for Nature Conservation 16, 1-11. 552 doi:10.1016/j.jnc.2007.03.004

553 Willis, A.J., Folkes, B.F., Hope-Simpson, J.F., Yemen, E.W. 1959. Braunton Burrows: the 554 dune system and its vegetation. Parts 1 and 2. Journal of Ecology 47, 1-24 and 249-288. 


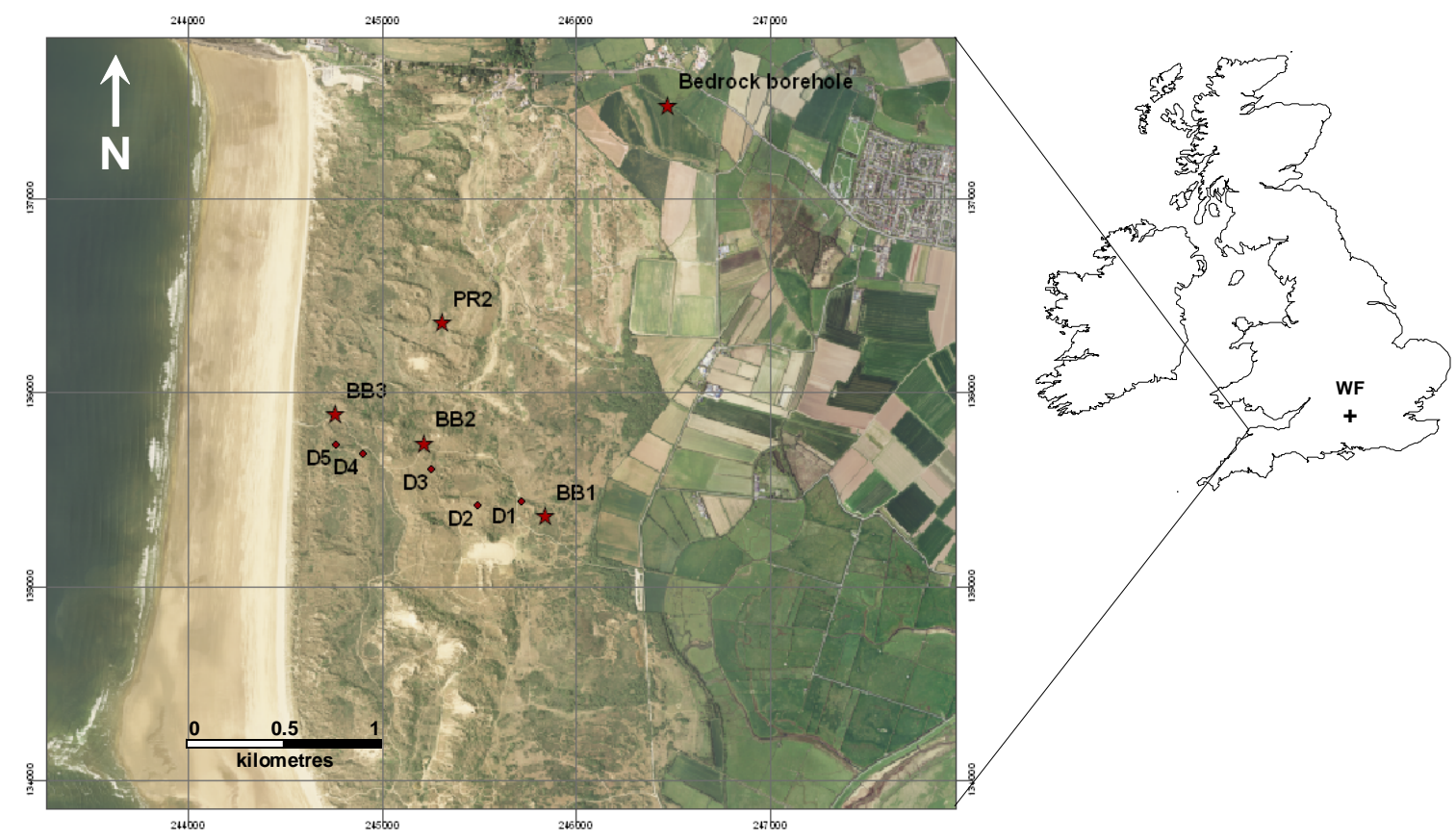

Figure 1. Map of Braunton Burrows, SW England, with key sites marked. Location of Wallingford (WF) shown on inset map. Based upon aerial photography from (C) NextPerspectives. 


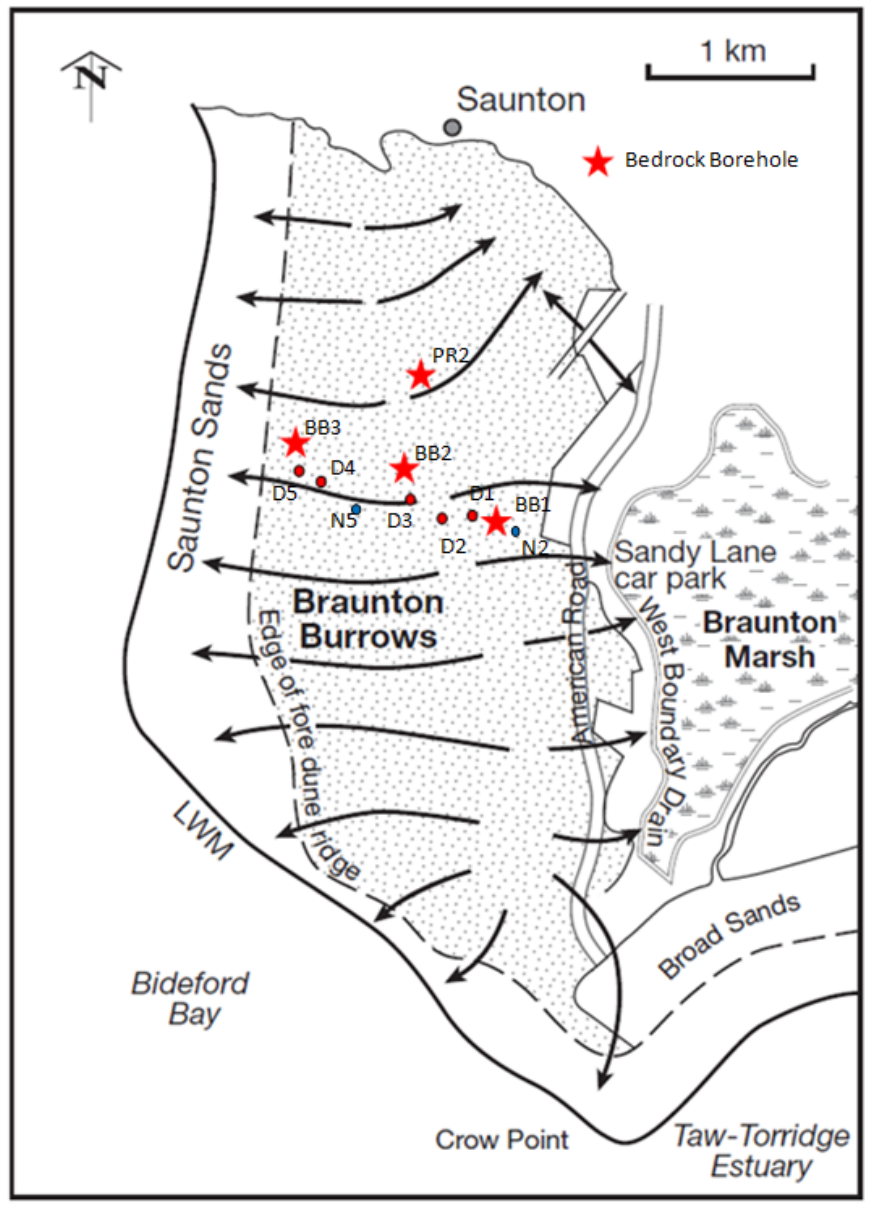

Figure 2. Conceptual groundwater flow at Braunton Burrows from Stratford et al (2013). 


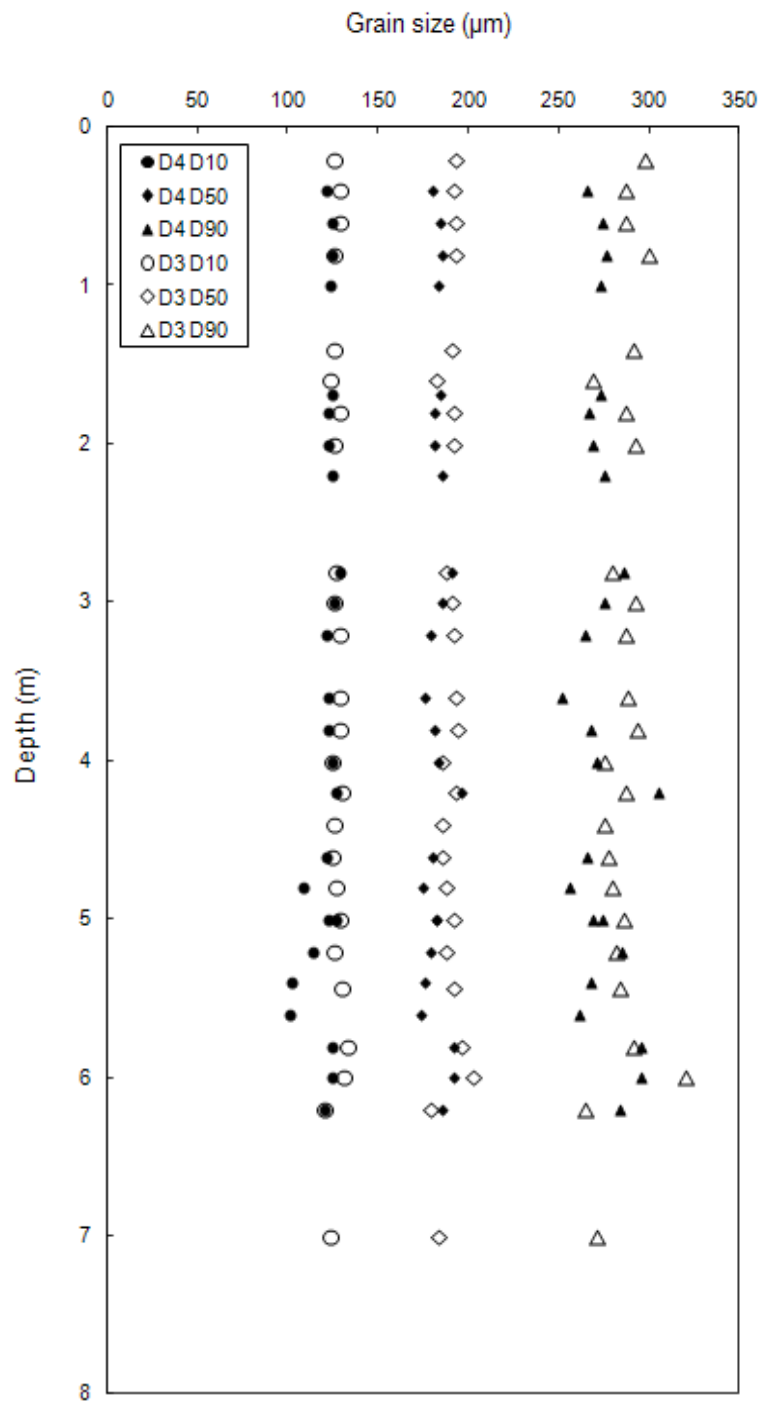

Figure 3. Results of grain size analysis for $\mathrm{D} 4$ showing $\mathrm{D}_{10}, \mathrm{D}_{50}$, and $\mathrm{D}_{90}$. 


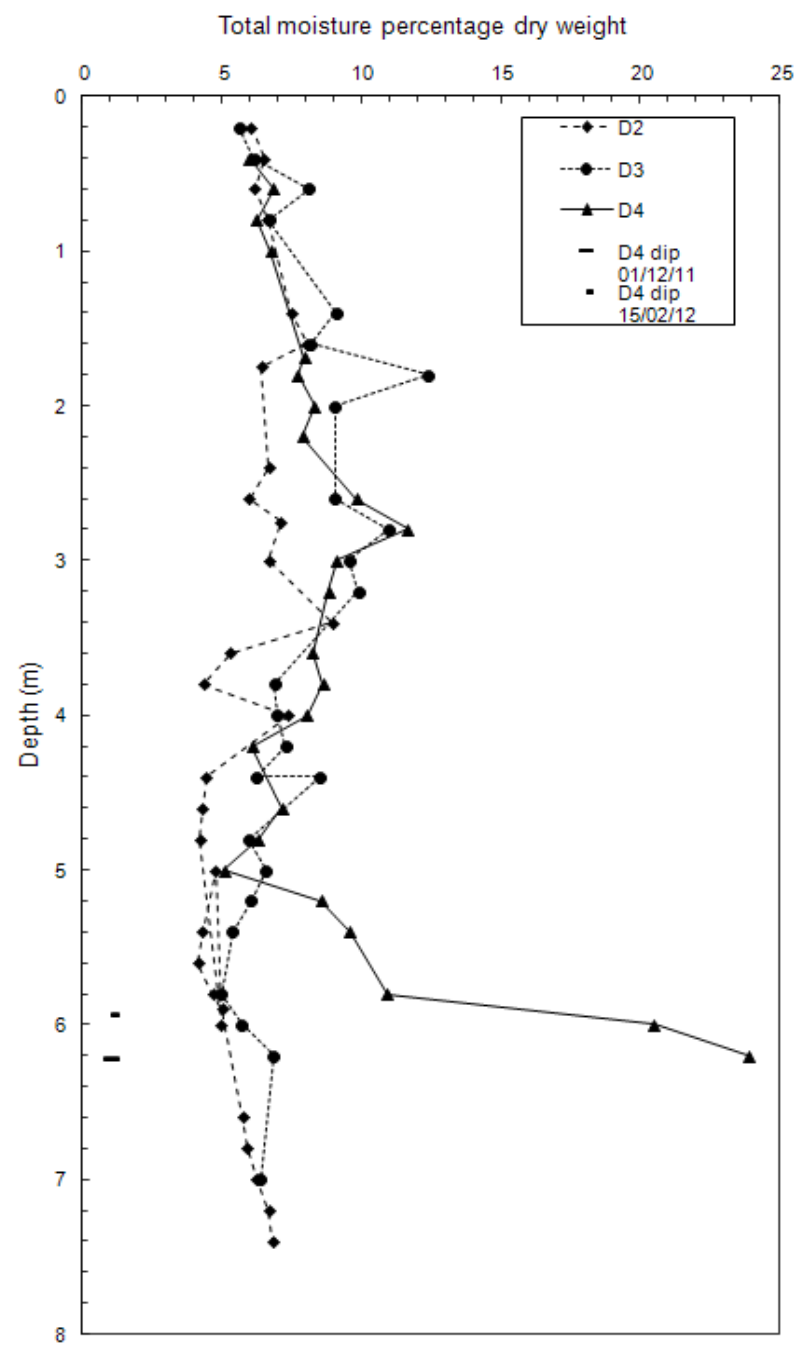

Figure 4. Moisture content depth profiles for piezometers D2, D3 and D4 showing water table in D4 in December 2011 and February 2012. 

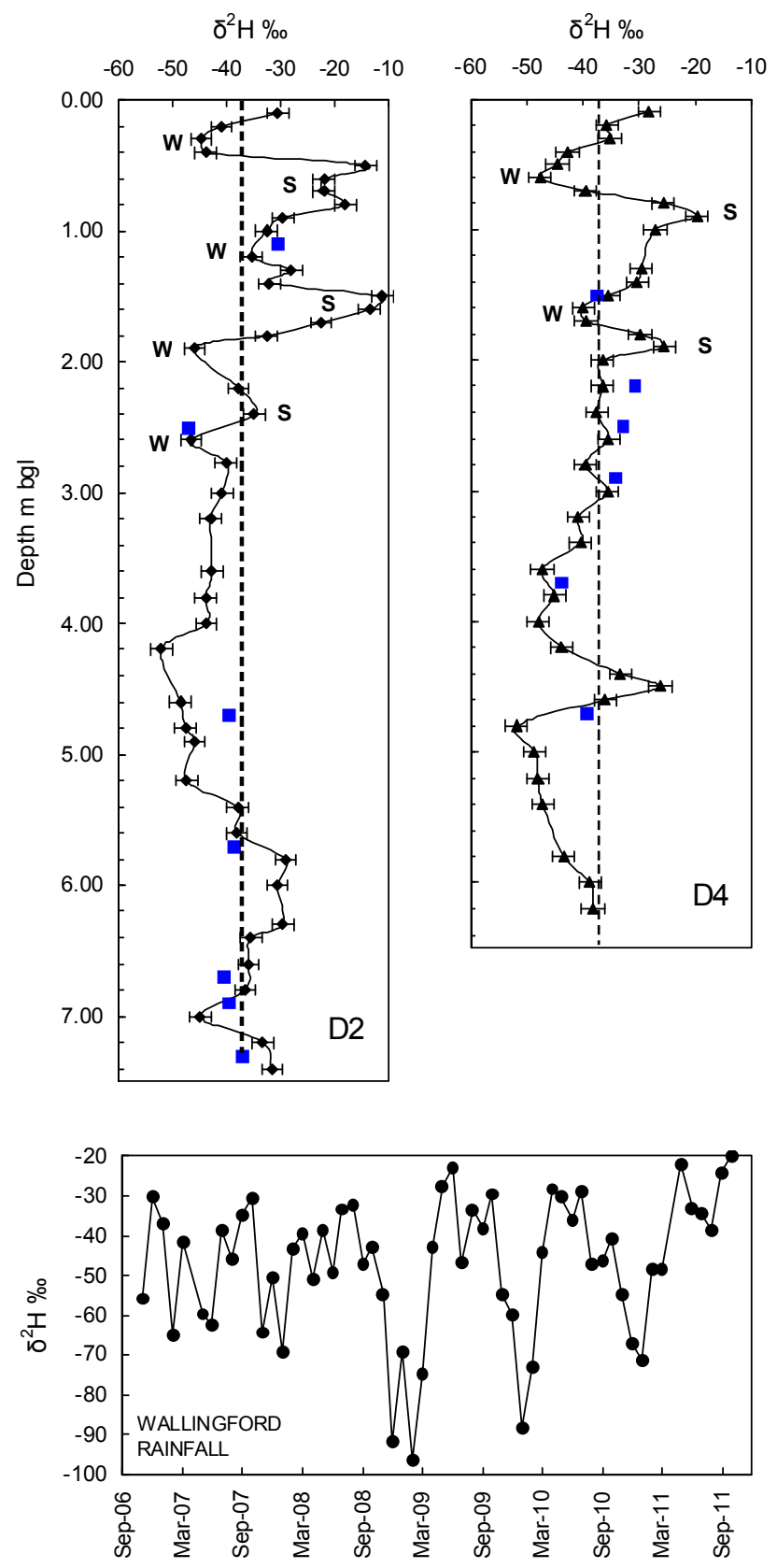

Figure 5. Profiles of $\delta^{2} \mathrm{H}$ in sand moisture from piezometers D2 and D4, autumn 2011.

Square datapoints represent analyses of water extracted by centrifuge, showing generally good agreement with the directly reduced sand moisture. Also shown is the rainfall isotope record from Wallingford (nearest rainfall isotope collection station) for the previous five years. The dashed vertical line shows the approximate $\delta^{2} \mathrm{H}$ composition of the underlying groundwater. Probable summer $(\mathrm{S})$ and winter $(\mathrm{W})$ peaks and troughs are identified on the profiles. 


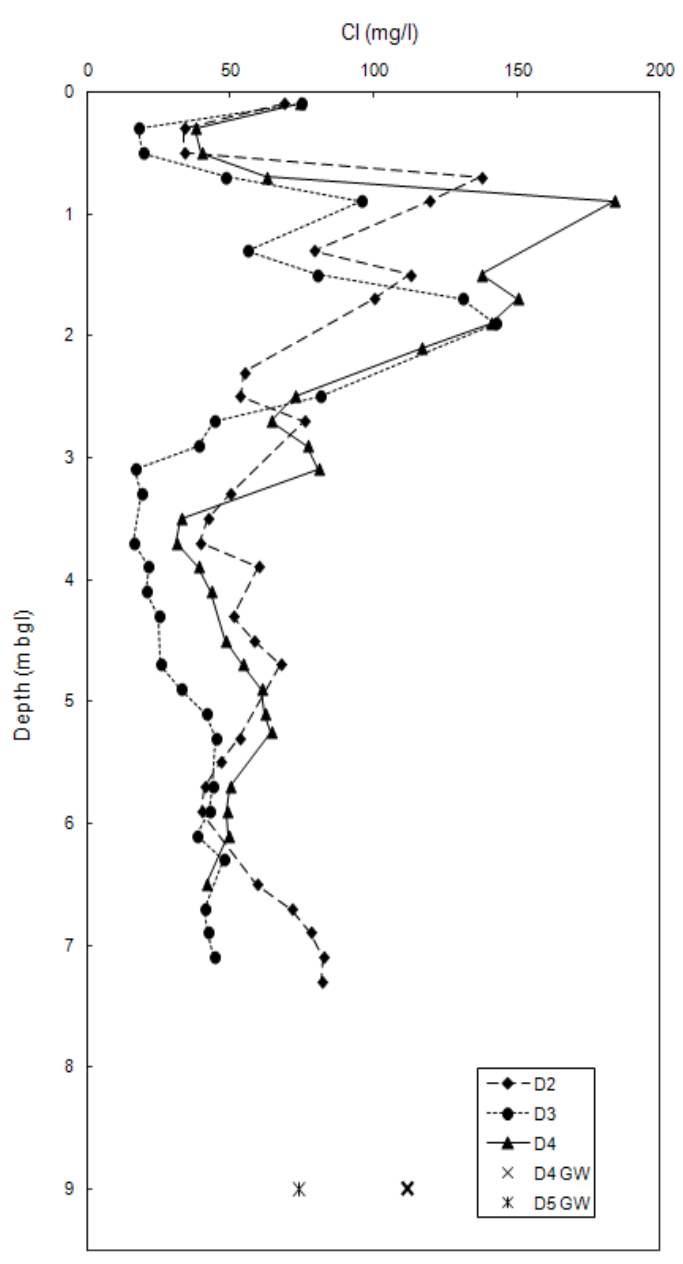

Figure 6. Concentration of chloride $(\mathrm{mg} / \mathrm{l})$ in the unsaturated zone below the high dunes. Data from centrifuged porewaters. 


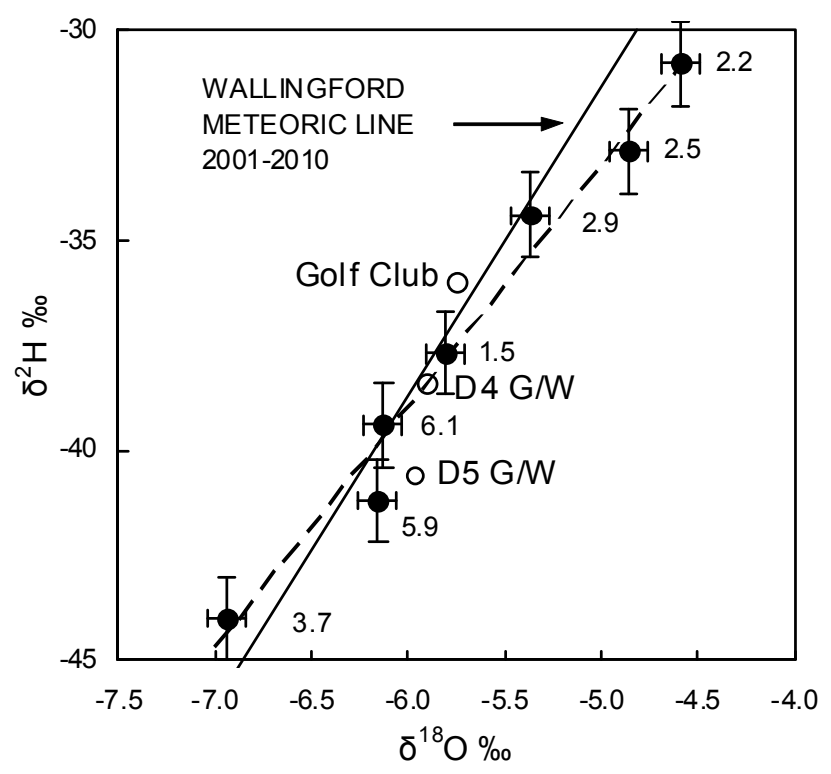

Figure 7. Isotopic co-plot showing the composition of centrifuged waters from the D4 profile compared to the meteoric line at Wallingford (WML), the nearest available GNIP network station (data from http://www.univie.ac.at/cartography/project/wiser/index.php). Sample depths are given in $\mathrm{m}$ bgl. Pumped groundwaters from piezometers D4 and D5 and the Golf Club (bedrock aquifer borehole are also included. The lack of significant deviation from the WML suggests that evaporation has little effect on the infiltrating water. 


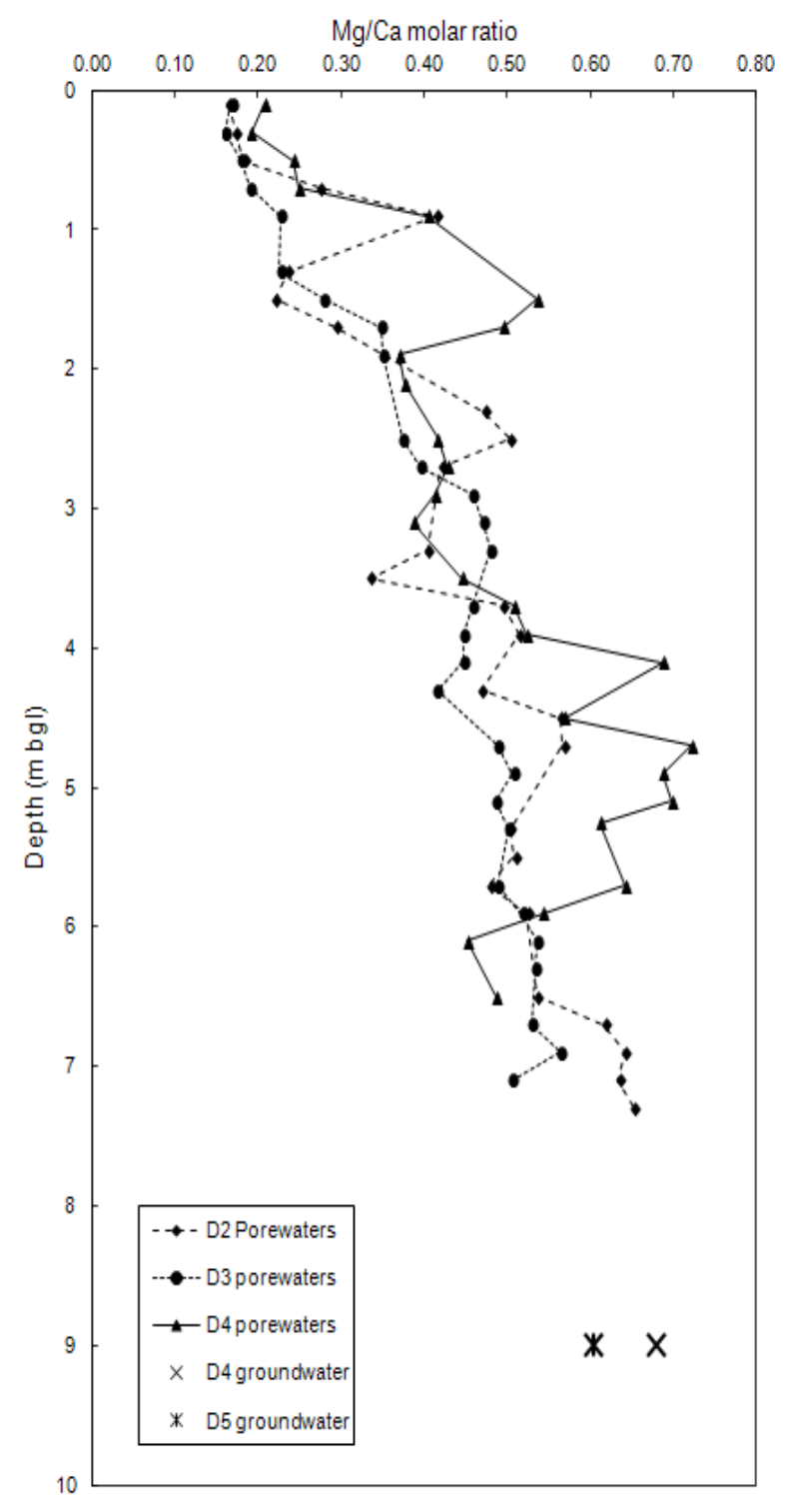

Figure 8. $\mathrm{Mg} / \mathrm{Ca}$ molar ratios for the porewaters and groundwaters of the high dunes. Groundwaters were sampled from approximately $9 \mathrm{~m} \mathrm{bgl}$. 


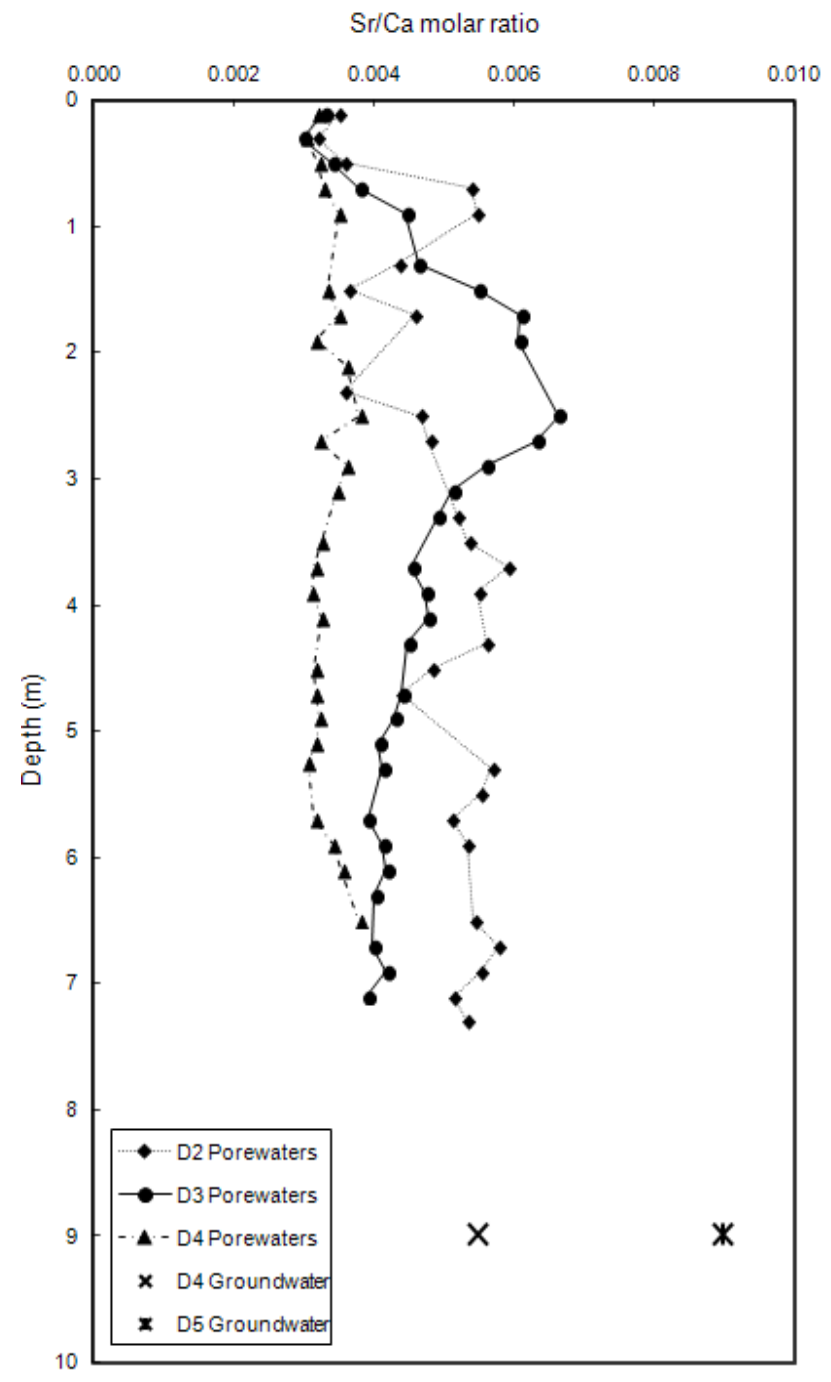

Figure 9. Porewater $\mathrm{Sr} / \mathrm{Ca}$ molar ratio with depth. 
Table 1. Construction details of sampled dune slack and high dune piezometers at Braunton Burrows, with water levels in mbgl (below ground level) at the time of sampling.

\begin{tabular}{lccccl}
\hline Dipwell & $\begin{array}{c}\text { Surface elev. } \\
(\mathbf{m})\end{array}$ & $\begin{array}{c}\text { Drilled Depth } \\
(\mathbf{m})\end{array}$ & $\begin{array}{c}\text { Water level } \\
(\mathbf{m b g l})\end{array}$ & Vegetation & Notes \\
\hline BB1 & 9.75 & 1.97 & top of casing & $\begin{array}{c}\text { SD14 wet calcareous slack type } \\
\text { SD16 dry calcareous type }\end{array}$ & Dune slack \\
BB2 & 9.76 & 1.97 & 0.51 & Dune slack \\
BB3 & 6.93 & 1.97 & 0.35 & SD16 + SD14 slack-dry transitional & Dune slack \\
PR2 & 9.42 & 2.52 & 0.79 & SD16 dry calcareous type & Dune slack \\
D1 & 16.14 & 6.00 & Dry & Fixed dune vegetation & \\
D2 & 25.20 & 8.62 & Dry & Fixed dune vegetation & \\
D3 & 17.03 & 8.62 & & Fixed dune vegetation & \\
Dnew3 & 17.03 & 9.20 & 8.38 & Fixed dune vegetation & \\
D4 & 13.09 & 8.62 & & Fixed dune vegetation & Casing removed \\
Dnew4 & 13.09 & 9.20 & 5.93 & Fixed dune vegetation & \\
D5 & 11.30 & 8.80 & & Fixed dune vegetation & Sediments risen to 5.93 mbgl by 17-Oct-12 \\
Dnew5 & 11.30 & 9.20 & 5.1 & Fixed dune vegetation & \\
\hline
\end{tabular}


Table 2. Major, selected minor and trace element analyses of dune porewaters from dipwells D2, D3 and D4.

\begin{tabular}{|c|c|c|c|c|c|c|c|c|c|c|c|c|c|c|c|}
\hline $\begin{array}{l}\text { Depth } \\
\text { mbgl }\end{array}$ & $\begin{array}{c}\text { SEC } \\
\mu \mathrm{S} \mathrm{cm}^{-1} \\
\end{array}$ & $\begin{array}{c}\mathrm{Ca} \\
\mathrm{mg} \mathrm{l}^{-1} \\
\end{array}$ & $\begin{array}{c}\mathrm{Mg} \\
\mathrm{mg} \mathrm{l}^{-1}\end{array}$ & $\begin{array}{c}\mathrm{Na} \\
\mathrm{mg} \mathrm{l}^{-1}\end{array}$ & $\begin{array}{c}\mathrm{K} \\
\mathrm{mg} \mathrm{l}^{-1} \\
\end{array}$ & $\begin{array}{l}\mathrm{HCO}_{3} \\
\mathrm{mg} \mathrm{l}^{-1} \\
\end{array}$ & $\begin{array}{c}\mathrm{Cl} \\
\mathrm{mg} \mathrm{l}^{-1} \\
\end{array}$ & $\begin{array}{c}\mathrm{SO}_{4} \\
\mathrm{mg} \mathrm{I}^{-1} \\
\end{array}$ & $\begin{array}{c}\mathrm{NO}_{3}-\mathrm{N} \\
\mathrm{mg} \mathrm{l}^{-1}\end{array}$ & $\begin{array}{c}\mathrm{NO}_{2}-\mathrm{N} \\
\mathrm{mg} \mathrm{l}^{-1} \\
\end{array}$ & $\begin{array}{c}\mathrm{Si} \\
\mathrm{mg} \mathrm{l}^{-1}\end{array}$ & $\begin{array}{l}\mathrm{Fe}_{\text {tot }} \\
\mu \mathrm{g} \mathrm{I}^{-1}\end{array}$ & $\begin{array}{c}\mathrm{Mn} \\
\mu \mathrm{g} \mathrm{I}^{-1}\end{array}$ & $\begin{array}{c}\mathrm{Sr} \\
\mu \mathrm{g} \mathrm{I}^{-1}\end{array}$ & $\begin{array}{c}\mathrm{PO}_{4}-\mathrm{P} \\
\mu \mathrm{g} \mathrm{I}^{-1}\end{array}$ \\
\hline \multicolumn{16}{|c|}{ Dipwell D2 } \\
\hline 0.1 & 605 & 79.8 & 7.99 & 33.9 & 11.8 & 171 & 68.4 & 74.7 & 8.90 & 0.088 & 1.93 & 33 & 13.7 & 612 & 180 \\
\hline 0.3 & 478 & 45.5 & 4.78 & 52.0 & 3.09 & 182 & 33.9 & 19.7 & 4.46 & 0.045 & 2.07 & 9 & 2.7 & 318 & $<30$ \\
\hline 0.5 & 432 & 46.2 & 5.11 & 36.6 & 2.65 & 178 & 33.5 & 18.0 & 1.33 & 0.033 & 2.00 & 13 & 0.6 & 363 & 34 \\
\hline 0.7 & 648 & 70.7 & 11.8 & 37.3 & 1.58 & 122 & 138 & 18.9 & 1.38 & $<0.006$ & 3.00 & 4 & 3.8 & 834 & $<50$ \\
\hline 0.9 & 635 & 61.5 & 15.5 & 41.7 & 1.70 & 153 & 119 & 24.1 & 0.964 & $<0.006$ & 3.15 & $<2$ & 22 & 736 & $<50$ \\
\hline 1.3 & 522 & 56.6 & 8.11 & 29.9 & 1.31 & 133 & 78.9 & 13.4 & 0.773 & $<0.003$ & 2.31 & $<2$ & 4.8 & 539 & $<30$ \\
\hline 1.5 & 570 & 68.6 & 9.17 & 25.2 & 1.47 & 101 & 113 & 13.6 & 0.900 & $<0.006$ & 2.32 & 3 & 3.1 & 545 & $<50$ \\
\hline 1.7 & 562 & 57.6 & 10.3 & 36.1 & 1.33 & 124 & 99.7 & 12.5 & 0.756 & $<0.003$ & 2.00 & $<6$ & 1.50 & 578 & 42 \\
\hline 2.3 & 529 & 52.7 & 15.1 & 58.8 & 2.90 & 166 & 54.5 & 29.2 & 2.12 & 0.035 & 2.12 & $<2$ & 4.2 & 414 & 45 \\
\hline 2.5 & 491 & 37.7 & 11.5 & 49.0 & 1.69 & 155 & 53.4 & 21.4 & 0.959 & 0.029 & 3.24 & $<2$ & 6.0 & 385 & 47 \\
\hline 2.7 & 548 & 49.1 & 12.5 & 48.5 & 1.60 & 165 & 75.5 & 18.7 & 0.694 & 0.031 & 3.20 & $<2$ & 14.9 & 514 & $<30$ \\
\hline 3.3 & 489 & 44.7 & 11.0 & 47.7 & 1.83 & 168 & 50.0 & 22.7 & 1.20 & 0.022 & 3.11 & 7 & 3.7 & 508 & 42 \\
\hline 3.5 & 423 & 43.4 & 8.81 & 34.8 & 1.38 & 150 & 42.0 & 18.3 & 1.31 & 0.026 & 2.92 & $<2$ & 6.6 & 507 & 42 \\
\hline 3.7 & & 37.4 & 11.2 & 44.5 & 1.73 & 158 & 39.4 & 26.9 & & 0.029 & 3.12 & 2 & 5.6 & 48 & 46 \\
\hline 3.9 & 505 & 38.8 & 12.1 & 48.9 & 2.20 & 161 & 59.5 & 27.6 & 1.19 & 0.033 & 3.00 & $<4$ & 5.6 & 465 & $<30$ \\
\hline 4.3 & 512 & 40.9 & 11.6 & 51.7 & 2.14 & 174 & 50.7 & 27.0 & 1.69 & 0.037 & 4.00 & $<4$ & 1.50 & 501 & 77 \\
\hline 4.5 & 535 & 39.9 & 13.7 & 56.4 & 2.31 & 164 & 58.3 & 28.8 & 1.72 & $<0.003$ & 4.00 & $<4$ & 0.9 & 422 & 47 \\
\hline 4.7 & 559 & 47.7 & 16.4 & 68.5 & 2.86 & 162 & 67.3 & 32.9 & 1.94 & 0.027 & 2.00 & $<4$ & 1.6 & 459 & 55 \\
\hline 5.3 & 497 & 43.3 & 13.2 & 44.8 & 2.17 & 162 & 53.0 & 23.3 & 1.64 & 0.031 & 3.46 & $<2$ & 1.4 & 537 & 81 \\
\hline 5.5 & 475 & 38.6 & 11.9 & 44.0 & 2.13 & 151 & 46.4 & 25.7 & 1.77 & 0.025 & 3.00 & $<4$ & 2.4 & 467 & 58 \\
\hline 5.7 & 470 & 53.1 & 15.4 & 51.3 & 2.51 & 182 & 40.8 & 23.2 & 1.59 & 0.025 & 4.00 & $<4$ & 2.0 & 594 & $<30$ \\
\hline 5.9 & 428 & 36.8 & 11.7 & 37.4 & 1.86 & 147 & 40.0 & 23.7 & 1.21 & 0.029 & 3.26 & $<2$ & 1.2 & 430 & 77 \\
\hline 6.5 & 574 & 46.4 & 15.1 & 52.1 & 3.11 & 188 & 59.2 & 32.8 & 1.94 & 0.039 & 3.93 & $<2$ & 1.2 & 551 & 65 \\
\hline 6.7 & 538 & 38.7 & 14.5 & 51.4 & 2.68 & 150 & 71.5 & 27.8 & 1.52 & $<0.003$ & 3.50 & 9 & 0.9 & 489 & 55 \\
\hline 6.9 & 578 & 42.9 & 16.7 & 52.2 & 2.77 & 166 & 77.9 & 29.6 & 1.60 & 0.028 & 3.50 & $<2$ & 0.9 & 519 & 49 \\
\hline 7.1 & 598 & 44.1 & 17.0 & 53.2 & 2.42 & 156 & 82.5 & 32.1 & 2.11 & 0.027 & 3.21 & 4 & 1.3 & 495 & 68 \\
\hline 7.3 & 600 & 45.2 & 17.9 & 53.9 & 3.01 & 167 & 81.8 & 32.1 & 1.47 & 0.024 & 3.62 & $<2$ & 1.0 & 527 & 63 \\
\hline Mean & & 50.5 & 12.4 & 47.6 & 2.86 & 162 & 68.8 & 28.7 & & 0.037 & 3.02 & 5 & 4.1 & 526 & 61 \\
\hline Min & 423 & 36.8 & 4.78 & 25.2 & 11.8 & 101 & 33.53 & 12.5 & 0.69 & $<0.003$ & 1.09 & $<2$ & 0.6 & 309 & $<30$ \\
\hline Max & 873 & 90.1 & 17.88 & 68.5 & 9.60 & 238 & 137.6 & 74.7 & 8.90 & 0.153 & 4.00 & 33 & 22 & 966 & 81 \\
\hline
\end{tabular}


Table 2 (contd). Major, selected minor and trace element analyses of dune porewaters from dipwells D2, D3 and D4.

\begin{tabular}{|c|c|c|c|c|c|c|c|c|c|c|c|c|c|c|c|}
\hline $\begin{array}{l}\text { Depth } \\
\text { mbgl }\end{array}$ & $\begin{array}{c}\text { SEC } \\
\mu \mathrm{S} \mathrm{cm}^{-1}\end{array}$ & $\begin{array}{c}\mathrm{Ca} \\
\mathrm{mg} \mathrm{l}^{-1} \\
\end{array}$ & $\begin{array}{c}\mathrm{Mg} \\
\mathrm{mg} \mathrm{l}^{-1} \\
\end{array}$ & $\begin{array}{c}\mathrm{Na} \\
\mathrm{mg} \mathrm{l}^{-1} \\
\end{array}$ & $\begin{array}{c}\mathrm{K} \\
\mathrm{mg} \mathrm{l}^{-1}\end{array}$ & $\begin{array}{l}\mathrm{HCO}_{3} \\
\mathrm{mg} \mathrm{l}^{-1}\end{array}$ & $\begin{array}{c}\mathrm{Cl} \\
\mathrm{mg} \mathrm{l}^{-1} \\
\end{array}$ & $\begin{array}{r}\mathrm{SO}_{4} \\
\mathrm{mg} \mathrm{l}^{-1} \\
\end{array}$ & $\begin{array}{l}\mathrm{NO}_{3}-\mathrm{N} \\
\mathrm{mg} \mathrm{l}^{-1}\end{array}$ & $\begin{array}{l}\mathrm{NO}_{2}-\mathrm{N} \\
\mathrm{mg} \mathrm{l}^{-1}\end{array}$ & $\begin{array}{c}\mathrm{Si} \\
\mathrm{mg} \mathrm{l}^{-1}\end{array}$ & $\begin{array}{l}\mathrm{Fe}_{\text {tot }} \\
\mu \mathrm{g} \mathrm{I}^{-1}\end{array}$ & $\begin{array}{c}\mathrm{Mn} \\
\mu \mathrm{g} \mathrm{I}^{-1}\end{array}$ & $\begin{array}{c}\mathrm{Sr} \\
\mu \mathrm{g} \mathrm{I}^{-1}\end{array}$ & $\begin{array}{r}\mathrm{PO}_{4}-\mathrm{P} \\
\mu \mathrm{g} \mathrm{I}^{-1}\end{array}$ \\
\hline \multicolumn{16}{|c|}{ Dipwell D3 } \\
\hline 0.1 & 820 & 109 & 11.1 & 48.1 & 11.0 & 204 & 74.4 & 30.4 & 32.7 & 0.078 & 4.80 & 34 & 14.3 & 780 & $<30$ \\
\hline 0.3 & 427 & 45.4 & 4.94 & 27.8 & 4.2 & 188 & 17.8 & 14.8 & 6.00 & 0.027 & 2.21 & 4 & 1.0 & 381 & 61 \\
\hline 0.5 & 362 & 49.9 & 5.77 & 39.3 & 2.6 & 169 & 19.3 & 11.6 & 1.53 & 0.025 & 2.42 & 2 & 0.6 & 337 & 67 \\
\hline 0.7 & 466 & 57.4 & 7.94 & 42.4 & 2.0 & 168 & 48.4 & 14.7 & 0.724 & 0.024 & 2.37 & $<2$ & 0.6 & 413 & 59 \\
\hline 0.9 & 571 & 84.8 & 10.2 & 51.7 & 16.1 & 149 & 95.4 & 14.0 & 0.370 & 0.105 & 4.25 & 3 & 1.6 & 560 & 44 \\
\hline 1.3 & 469 & 50.4 & 6.92 & 40.6 & 1.6 & 166 & 56.0 & 10.2 & 0.509 & 0.023 & 2.14 & 22 & 1.0 & 511 & 50 \\
\hline 1.5 & 539 & 57.2 & 9.72 & 34.1 & 1.3 & 165 & 80.3 & 12.0 & 0.503 & 0.023 & 2.84 & $<2$ & 0.9 & 684 & 47 \\
\hline 1.7 & 585 & 60.8 & 12.9 & 28.0 & 1.4 & 135 & 130.7 & 16.5 & 0.616 & $<0.006$ & 2.57 & $<2$ & 0.6 & 809 & 88 \\
\hline 1.9 & 646 & 68.1 & 14.4 & 32.2 & 1.8 & 145 & 142.3 & 15.6 & 0.615 & $<0.006$ & 2.97 & 3 & 1.1 & 903 & 94 \\
\hline 2.5 & 550 & 60.3 & 13.7 & 29.7 & 1.5 & 169 & 81.0 & 13.4 & 0.519 & 0.023 & 2.89 & $<2$ & 0.4 & 874 & 42 \\
\hline 2.7 & 491 & 55.1 & 13.2 & 26.7 & 1.4 & 173 & 44.3 & 10.5 & 0.362 & $<0.003$ & 2.88 & $<2$ & 0.3 & 761 & 62 \\
\hline 2.9 & 439 & 44.0 & 12.2 & 24.9 & 1.3 & 192 & 39.0 & 12.1 & 0.445 & 0.023 & 2.72 & $<2$ & 0.2 & 539 & 56 \\
\hline 3.1 & 341 & 33.2 & 9.51 & 22.2 & 1.1 & 167 & 16.7 & 12.0 & 0.816 & 0.023 & 2.40 & $<2$ & 0.7 & 372 & 48 \\
\hline 3.3 & 372 & 39.1 & 11.4 & 24.2 & 1.4 & 183 & 19.0 & 11.6 & 0.375 & $<0.003$ & 2.80 & $<2$ & 0.7 & 420 & 49 \\
\hline 3.7 & 370 & 35.9 & 9.97 & 25.5 & 1.5 & 183 & 16.1 & 14.1 & 0.940 & 0.024 & 3.07 & $<2$ & 0.7 & 357 & 67 \\
\hline 3.9 & 381 & 37.7 & 10.2 & 29.2 & 1.5 & 174 & 21.4 & 14.4 & 1.10 & 0.030 & 2.87 & 2 & 1.1 & 390 & 53 \\
\hline 4.1 & 386 & 37.5 & 10.2 & 29.9 & 1.7 & 182 & 20.6 & 14.2 & 1.10 & 0.032 & 3.15 & 4 & 0.9 & 392 & 51 \\
\hline 4.3 & 392 & 37.5 & 9.46 & 32.5 & 1.4 & 164 & 25.1 & 17.3 & 1.39 & 0.029 & 2.91 & 3 & 0.9 & 368 & 75 \\
\hline 4.7 & 407 & 38.6 & 11.5 & 29.0 & 1.7 & 190 & 25.3 & 14.8 & 1.11 & 0.026 & 2.85 & $<2$ & 1.4 & 371 & 51 \\
\hline 4.9 & 451 & 43.1 & 13.3 & 33.0 & 2.0 & 201 & 32.6 & 15.7 & 1.04 & 0.026 & 3.05 & $<2$ & 1.2 & 405 & 52 \\
\hline 5.1 & 452 & 40.6 & 12.0 & 38.2 & 2.1 & 172 & 41.7 & 19.6 & 1.36 & 0.035 & 2.94 & $<2$ & 1.5 & 362 & 55 \\
\hline 5.3 & 460 & 40.0 & 12.2 & 33.3 & 2.1 & 170 & 44.6 & 19.2 & 1.07 & 0.040 & 2.7 & 9 & 1.2 & 360 & 49 \\
\hline 5.7 & 492 & 42.7 & 12.7 & 42.6 & 2.4 & 194 & 43.7 & 21.1 & 1.26 & 0.040 & 3.23 & 3 & 0.9 & 366 & 69 \\
\hline 5.9 & 456 & 40.1 & 12.6 & 44.1 & 2.4 & 166 & 42.6 & 21.9 & 1.40 & 0.034 & 2.97 & 7 & 1.3 & 361 & 59 \\
\hline 6.1 & 463 & 38.3 & 12.5 & 39.0 & 2.5 & 184 & 38.3 & 19.0 & 1.14 & 0.031 & 3.10 & $<2$ & 0.7 & 351 & 61 \\
\hline 6.3 & 477 & 39.4 & 12.8 & 40.4 & 2.3 & 173 & 47.8 & 21.1 & 0.851 & 0.030 & 2.84 & $<2$ & 0.7 & 346 & 64 \\
\hline 6.9 & 467 & 38.9 & 13.3 & 41.3 & 2.6 & 176 & 41.9 & 21.6 & 2.03 & 0.029 & 2.95 & 3 & 1.1 & 355 & 64 \\
\hline 7.1 & 487 & 39.6 & 12.2 & 42.6 & 2.8 & 180 & 44.0 & 23.6 & 1.57 & 0.031 & 3.30 & $<2$ & 0.6 & 338 & 58 \\
\hline Mean & 496 & 49.5 & 11.19 & 35.9 & 2.86 & 179 & 50.9 & 19.5 & 2.61 & 0.032 & 2.94 & 4.38 & 1.44 & 497.1 & 57 \\
\hline Min & 341.1 & 33.2 & 4.9 & 22.2 & 1.1 & 135 & 16.1 & 10.2 & 0.36 & $<0.003$ & 1.2 & $<2$ & 0.2 & 337 & $<30$ \\
\hline $\operatorname{Max}$ & 820 & 108.5 & 14.78 & 54.5 & 16.1 & 261 & 142 & 70.4 & 32.65 & 0.105 & 4.80 & 34 & 14.3 & 902.5 & 94 \\
\hline
\end{tabular}


Table 2 (contd). Major, selected minor and trace element analyses of dune porewaters from dipwells D2, D3 and D4.

\begin{tabular}{|c|c|c|c|c|c|c|c|c|c|c|c|c|c|c|c|}
\hline $\begin{array}{l}\text { Depth } \\
\text { mbgl }\end{array}$ & $\begin{array}{r}\mathrm{SEC} \\
\mu \mathrm{S} \mathrm{cm}\end{array}$ & $\begin{array}{r}\mathrm{Ca} \\
\mathrm{mg} \mathrm{l} \\
\end{array}$ & $\begin{array}{c}\mathrm{Mg} \\
\mathrm{mg} \mathrm{l}^{-1}\end{array}$ & $\begin{array}{c}\mathrm{Na} \\
\mathrm{mg} \mathrm{l}^{-1} \\
\end{array}$ & $\begin{array}{c}\mathrm{K} \\
\mathrm{mg} \mathrm{l}^{-1} \\
\end{array}$ & $\begin{array}{l}\mathrm{HCO}_{3} \\
\mathrm{mg} \mathrm{l}^{-1}\end{array}$ & $\begin{array}{c}\mathrm{Cl} \\
\mathrm{mg} \mathrm{l}^{-1}\end{array}$ & $\begin{array}{c}\mathrm{SO}_{4} \\
\mathrm{mg} \mathrm{l}^{-1} \\
\end{array}$ & $\begin{array}{l}\mathrm{NO}_{3}-\mathrm{N} \\
\mathrm{mg} \mathrm{l}^{-1}\end{array}$ & $\begin{array}{l}\mathrm{NO}_{2}-\mathrm{N} \\
\mathrm{mg} \mathrm{l}^{-1}\end{array}$ & $\begin{array}{c}\mathrm{Si} \\
\mathrm{mg} \mathrm{l}^{-1}\end{array}$ & $\begin{array}{l}\mathrm{Fe}_{\text {tot }} \\
\mu \mathrm{g} \mathrm{I}^{-1}\end{array}$ & $\begin{array}{c}\mathrm{Mn} \\
\mu \mathrm{g} \mathrm{I}^{-1}\end{array}$ & $\begin{array}{l}\mathrm{Sr} \\
\mathrm{g}^{-1}\end{array}$ & $\begin{array}{l}\mathrm{PO}_{4}-\mathrm{P} \\
\mu \mathrm{g} \mathrm{I}^{-1}\end{array}$ \\
\hline \multicolumn{16}{|c|}{ Dipwell D4 } \\
\hline 0.1 & 739 & 93.5 & 11.75 & 41.1 & 7.6 & 277.3 & 73.9 & 27.2 & 3.22 & $<0.003$ & 2.46 & 38 & 19.1 & 654 & 106 \\
\hline 0 & 581 & 67.1 & 7.81 & 44.1 & 2.7 & 258.2 & 37.4 & 17.0 & 3.68 & 0.034 & 2.16 & 6 & 1.3 & 445 & 92 \\
\hline 5 & 490 & 48.7 & 7.17 & 54.8 & 1.7 & 195.9 & 39.7 & 17.7 & 1.43 & 0.033 & 2.76 & 3 & 1.1 & 343 & 69 \\
\hline & 619 & 55.8 & 8.4 & 61.6 & 1.4 & 224.1 & 62.4 & 21.0 & 0.886 & 0.032 & 2.37 & 2 & 1.0 & 400 & 59 \\
\hline 0 & 762 & 71.2 & 17.44 & 46.0 & 1.5 & 137.3 & 184.0 & 12.9 & 1.20 & 0.047 & 2.65 & 3 & 2.5 & 547 & 93 \\
\hline & 715 & 59.7 & 19.44 & 52.3 & 2.3 & 163.6 & 137.6 & 16.4 & 0.804 & 0.044 & 2.86 & $<2$ & 1.2 & 435 & 83 \\
\hline & 687 & 61.2 & 18.36 & 47.6 & 2.6 & 161.3 & 150.1 & 14.5 & 0.914 & 0.044 & 2.51 & 2 & 1.0 & 470 & 69 \\
\hline & 09 & 70.7 & 15.84 & 52.3 & 2.5 & 160.5 & 141.0 & 16.0 & 0.867 & 0.045 & 2.27 & $<2$ & 1.4 & 489 & 87 \\
\hline & 639 & 65.6 & 15.01 & 34.2 & 2.3 & 147.9 & 116.4 & 15.4 & 0.579 & 0.044 & 3.08 & $<2$ & 0.7 & 519 & 73 \\
\hline & & & 13.89 & 26.3 & 2.0 & 170.9 & 72.2 & & & & 2.55 & & 0.3 & & 66 \\
\hline 2 & 483 & 47.3 & 12.27 & 33.6 & 2.2 & 162 & 64.0 & 15.3 & 0.831 & 0.044 & 2.79 & 3 & 0.9 & 3 & 93 \\
\hline & 531 & & 13.52 & & 2.3 & 170.5 & 76.6 & & & 43 & 2.27 & 3 & 0.4 & 42 & 82 \\
\hline 3.1 & 524 & 54.8 & 12.87 & 30.2 & 1.8 & 148.7 & 80.4 & 14.7 & 0.621 & 0.043 & 3.45 & $<2$ & 0.3 & 417 & 62 \\
\hline & 434 & 45.6 & 12.32 & 27.0 & 2.0 & 199.2 & 32.5 & 14.6 & 0.519 & 0.043 & 2.61 & $<2$ & 0.5 & 324 & 69 \\
\hline 3. & 412 & 41.7 & 12.85 & 26.7 & 2.4 & 188.6 & 31.0 & 16.5 & 0.907 & 0.045 & 2.82 & 2 & 0.6 & 28 & 98 \\
\hline & 458 & 44.9 & 14.25 & 33.5 & 3.1 & 195.2 & 38.5 & 17.5 & 87 & 0.044 & 2.80 & 4 & 0.4 & 30 & 75 \\
\hline 4.1 & 513 & 41.2 & 17.18 & 39.5 & 4.0 & 215.5 & 42.9 & 20.6 & 1.85 & 0.046 & 3.91 & 2 & 1.0 & 293 & 69 \\
\hline & & 45.7 & 15.74 & 39.5 & 3.4 & 203.4 & 48.1 & 22.5 & 1.62 & 0.045 & 2.68 & $<2$ & 0.6 & 316 & 76 \\
\hline 4.7 & 544 & 41.8 & 18.31 & 44.0 & 4.1 & 196.4 & 54.0 & 24.0 & 2.25 & $<0.003$ & 1.94 & 7 & 1.1 & 290 & 83 \\
\hline 4.9 & 604 & 47.6 & 19.86 & 48.7 & 4.8 & 203.1 & 60.7 & 31.8 & 3.06 & $<0.003$ & 2.76 & 4 & 1.4 & 335 & 80 \\
\hline 5.1 & 579 & 47.2 & 20 & 43.4 & 4.0 & 177.4 & 62.1 & 31.0 & 5.32 & $<0.003$ & 2.87 & 3 & 0.8 & 328 & 80 \\
\hline 5.25 & 562 & 43.9 & 16.31 & 42.9 & 3.9 & 157.1 & 63.9 & 29.5 & 5.22 & $<0.003$ & 4.3 & 3 & 1.3 & 29 & 88 \\
\hline 5.7 & 493 & 41 & 15.97 & 37.1 & 3.3 & 176.9 & 50.0 & 20.2 & 2.30 & $<0.003$ & 3.05 & 3 & 1.1 & 283 & 82 \\
\hline 5.9 & 474 & 42.2 & 13.91 & 37.9 & 2.7 & 192.4 & 48.7 & 14.6 & 0.882 & $<0.003$ & 3.02 & $<2$ & $<0.2$ & 317 & 59 \\
\hline 6.1 & 518 & 46.6 & 12.76 & 44.7 & 2.7 & 210.2 & 49.4 & 11.9 & 0.245 & $<0.003$ & 3.00 & $<2$ & $<0.2$ & 361 & 59 \\
\hline 6.5 & 439 & 37.6 & 11.1 & 39.8 & 2.40 & 157.6 & 41.3 & 22.0 & 1.71 & 0.044 & 13.8 & $<4$ & $<0.4$ & 312 & 117 \\
\hline & & & 15.08 & 45.1 & 3.35 & & 79.49 & & 1.873 & & 2.77 & 4.35 & 2.1 & & 80 \\
\hline & 412 & 37.6 & 7.17 & 26.3 & 1.43 & 137.3 & 30.99 & 11.95 & 0.245 & $<0.006$ & 1.94 & $<2$ & $<2$ & 282.9 & $<50$ \\
\hline Max & 936 & 93.5 & 24.41 & 82.5 & 10.5 & 277.3 & 218.8 & 88.4 & 5.321 & 0.0517 & 4.38 & 38 & 19.1 & 653.5 & 117 \\
\hline
\end{tabular}


Table 3. Major, selected minor and trace element chemistry and stable isotope composition of groundwaters from the Braunton dune system.

\begin{tabular}{|c|c|c|c|c|c|c|c|c|c|c|c|c|c|c|c|c|c|c|c|c|c|c|c|}
\hline Site ID & Date & $\begin{array}{c}\text { Temp } \\
\left({ }^{\circ} \mathrm{C}\right) \\
\end{array}$ & $\mathbf{p H}$ & $\begin{array}{r}\text { Eh } \\
(\mathrm{mV}) \\
\end{array}$ & $\begin{array}{c}\text { DO } \\
\mathrm{mg} \mathrm{l}^{-1} \\
\end{array}$ & $\begin{array}{c}\text { SEC } \\
\mu \mathrm{S} \mathrm{cm}^{-1} \\
\end{array}$ & $\begin{array}{c}\mathrm{Ca} \\
\mathrm{mg} \mathrm{l}^{-1} \\
\end{array}$ & $\begin{array}{c}\mathrm{Mg} \\
\mathrm{mg} \mathrm{l}^{-1} \\
\end{array}$ & $\begin{array}{c}\mathrm{Na} \\
\mathrm{mg} \mathrm{l}^{-1} \\
\end{array}$ & $\begin{array}{c}\mathrm{K} \\
\mathrm{mg} \mathrm{l}^{-1} \\
\end{array}$ & $\begin{array}{l}\mathrm{HCO}_{3} \\
\mathrm{mg} \mathrm{l}^{-1} \\
\end{array}$ & $\begin{array}{c}\mathrm{Cl} \\
\mathrm{mg} \mathrm{l}^{-1} \\
\end{array}$ & $\begin{array}{c}\mathrm{SO}_{4} \\
\mathrm{mg} \mathrm{l}^{-1} \\
\end{array}$ & $\begin{array}{l}\mathrm{NO}_{3}-\mathrm{N} \\
\mathrm{mg} \mathrm{l}^{-1} \\
\end{array}$ & $\begin{array}{l}\mathrm{NO}_{2}-\mathrm{N} \\
\mathrm{mg} \mathrm{l}^{-1} \\
\end{array}$ & $\begin{array}{c}\mathrm{Si} \\
\mathrm{mg} \mathrm{l}^{-1} \\
\end{array}$ & $\begin{array}{c}F_{e_{\text {tot }}} \\
\mu \mathrm{g} \mathrm{l}^{-1} \\
\end{array}$ & $\begin{array}{c}\mathrm{Mn} \\
\mu \mathrm{g} \mathrm{I}^{-1} \\
\end{array}$ & $\begin{array}{c}\mathrm{Sr} \\
\mu \mathrm{g} \mathrm{I}^{-1} \\
\end{array}$ & $\begin{array}{c}P \\
\mu \mathrm{g} \mathrm{I}^{-1} \\
\end{array}$ & $\begin{array}{c}\delta^{18} \mathrm{O} \\
\% \mathrm{O} \\
\end{array}$ & $\begin{array}{c}\delta^{2} H \\
\% 0 \\
\end{array}$ & $\begin{array}{c}\delta^{13} \mathrm{C}_{\mathrm{DIC}} \\
\% \text { o } \\
\end{array}$ \\
\hline \multicolumn{24}{|c|}{ Dune slack } \\
\hline 1 & $25-F e b-10$ & 7.9 & 7.30 & 139 & 0.4 & 719 & 101.2 & 14.6 & 24.8 & 1.9 & 373 & 41.3 & 8.08 & 0.01 & $<0.006$ & 5.23 & 928.2 & 972.6 & 1566 & $<30$ & nd & nd & nd \\
\hline 2 & 25-Feb-10 & 8.9 & 7.53 & 133 & 0.2 & 597 & 81.5 & 11.1 & 28.3 & 1.1 & 291 & 42.3 & 5.17 & 0.01 & $<0.006$ & 3.29 & 613.2 & 244.8 & 725 & $<30$ & nd & nd & nd \\
\hline 3 & 25-Feb-10 & 8.3 & 7.67 & 248 & 0.2 & 835 & 68.3 & 22.0 & 68.0 & 3.8 & 307 & 94.5 & 20.47 & $<.01$ & $<0.006$ & 2.51 & 11.3 & 4.2 & 959 & $<30$ & nd & nd & nd \\
\hline PR2 & 15-Nov-12 & 12.2 & 7.57 & 148 & 0.5 & 599 & 58.6 & 22.5 & 77.8 & 3.9 & 306 & 120.5 & 38.58 & 2.43 & $<0.006$ & 3.94 & 106.4 & 163.0 & nd & $<30$ & -5.40 & -34.9 & -8.9 \\
\hline \multicolumn{24}{|l|}{ High dune } \\
\hline D4 & 15-Feb-12 & 10.4 & 7.93 & -190 & 1.1 & 804 & 65.1 & 26.8 & 54.2 & 4.0 & 285 & 111.3 & 21.16 & 0.95 & $<0.003$ & 3.66 & 231 & 470 & 779 & $<10$ & -5.90 & -38.4 & -9.5 \\
\hline D5 & 15-Feb-12 & 12.1 & 7.98 & -318 & 0.5 & 687 & 62.6 & 23.0 & 43.7 & 2.8 & 330 & 73.2 & 15.99 & 0.01 & $<0.003$ & 3.75 & 303 & 566 & 1230 & $<10$ & -5.97 & -40.6 & -9.3 \\
\hline \multicolumn{24}{|c|}{ Pilton Mudstone formation } \\
\hline Golf Club & 14-Nov-12 & 12.0 & 7.20 & 231 & 0.9 & 877 & 72.4 & 16.7 & 28.4 & 1.5 & 254 & 43.02 & 7.15 & 0.02 & $<0.003$ & 4.35 & 94.4 & 136.6 & nd & $<10$ & -5.82 & -35.9 & -13.6 \\
\hline
\end{tabular}


Table 4. $\mathrm{SF}_{6}$ concentrations as measured and also corrected for excess air inputs (see text), with calculated mean residence times (MRTs) for groundwater below dune slacks and high dunes.

\begin{tabular}{lccccc}
\hline Dipwell & Site type & Date & $\begin{array}{c}\mathbf{S F}_{\mathbf{6}} \\
(\mathbf{f m o l} / \mathbf{L})\end{array}$ & $\begin{array}{c}\mathbf{S F}_{\mathbf{6}} \text { corr. } \\
(\mathbf{f m o l} / \mathbf{L})\end{array}$ & $\begin{array}{c}\text { MRT } \\
(\mathbf{y r})\end{array}$ \\
\hline D1 & Dune slack & 25-Feb-10 & 2.65 & 2.29 & $6 \pm 2$ \\
D2 & Dune slack & 25-Feb-10 & 2.49 & 2.15 & $7 \pm 2$ \\
D3 & Dune slack & 25-Feb-10 & 2.73 & 2.36 & $6 \pm 2$ \\
Dnew4 & High dune & 15-Feb-12 & 1.76 & 1.52 & $16 \pm 2$ \\
Dnew5 & High dune & 15-Feb-12 & 2.06 & 1.78 & $13 \pm 2$ \\
Golf Club & Bedrock & 14-Nov-12 & 1.31 & 1.04 & $22 \pm 2.5$ \\
\hline
\end{tabular}

